\title{
Spatio-temporal variation of cyanobacteria and cyanotoxins in public supply reservoirs of the semi-arid region of Brazil
}

\author{
Ranielle Daiana dos Santos Silva, ${ }^{1}$ Juliana dos Santos Severiano, ${ }^{1 *}$ Dayany Aguiar de Oliveira, ${ }^{1}$ Camila Ferreira Mendes, \\ Vanessa Virgínia Barbosa, ${ }^{1}$ Mathias Ahii Chia, ${ }^{2}$ José Etham de Lucena Barbosa ${ }^{1}$
}

${ }^{1}$ Laboratório de Ecologia Aquática, Centro de Ciências Biológicas, Programa de Pós-Graduação em Ecologia e Conservação, Departamento de Biologia, Universidade Estadual da Paraíba, Rua Baraúnas 351, Bairro Universitário, 58429-500, Campina Grande (PB), Brazil; ${ }^{2}$ Department of Botany, Ahmadu Bello University, Zaria, Nigeria

\begin{abstract}
Cyanobacteria harmful algal blooms (CyanoHABs) have become increasingly frequent and intense in public supply reservoirs as a result of eutrophication and global climate change. The semi-arid region of Brazil has a well documented history of CyanoHABs but the underlying factors that control the excessive proliferation of these organisms and the production of their bioactive secondary metabolites are not comprehensively understood. This study aimed to identify the environmental factors that explain the spatial and temporal variations in the abundance of cyanobacteria and the concentration of cyanotoxins (microcystins, saxitoxins, and cylindrospermopsin) in semi-arid reservoirs. The following hypotheses were tested: i) the largest biovolumes of potential toxin producing cyanobacteria occur when cyanotoxin concentrations are highest; and ii) the environmental factors that explain variations in biovolume of cyanobacteria also explain changes in cyanotoxins concentrations. Samples were taken from four reservoirs located in the Northeast region of Brazil, over a threemonth period (October 2016 and February and June 2017). Of the 24 species of cyanobacteria identified, 13 were potentially toxin-producing. Physicochemical variables such as water volume of the reservoir, water transparency, soluble reactive phosphorus, and total phosphorus explained the abundance of cyanobacteria and the levels of cyanotoxins. These results corroborate the hypothesis that similar physicochemical conditions influence the abundance and diversity of cyanobacteria and cyanotoxins. Cyanobacterial blooms composed of more than one potential toxin producing species were observed in the studied reservoirs, where potential microcystin-producing species were the most common. Microcystins and saxitoxins were detected in all the reservoirs studied, while cylindrospermopsin and the cyanobacterium Cylindrospermopsis raciborskii were simultaneously recorded in only one reservoir (Camalaú Reservoir). Cylindrospermopsin was only detected in a reservoir for the first time in the State of Paraíba. Canonical redundancy analysis showed that the cyanotoxins were related to potential toxin producing species. These results corroborate the proposed hypothesis that there is a correlation between cyanotoxins and the biomass of potential producers. Also, there were situations where cyanotoxins were detected without the presence of potential producers. These results demonstrate the need for reassessment of potential toxin producing species of cyanobacteria in semi-arid reservoirs. This may lead to the identification and characterization of novel producers of these bioactive secondary metabolites.
\end{abstract}

Corresponding author: jsantosseveriano@gmail.com

Key words: Eutrophication; cylindrospermopsins; microcystins; saxitoxins; tropical reservoirs.

Edited by: Andrea Lami, CNR-IRSA Verbania, Italy.

Contributions: JSS, MAC, JELB, study concept; JSS, RDSS, DAO, CFM, VVB, data curation; RDSS, DAO, CFM, VVB, formal analysis; RDSS, CFM, VVB, methodology; JSS, MAC, JELB, resources and supervision; RDSS, original manuscript draft; RDSS, JSS, MAC, JELB, manuscript review and editing. All authors read and approved the final version to be published.

Conflict of interests: the authors declare no potential conflict of interests

Received: 11 February 2019.

Accepted: 16 September 2019.

This work is licensed under a Creative Commons Attribution NonCommercial 4.0 License (CC BY-NC 4.0).

${ }^{\circ}$ Copyright: the Author(s), 2019

Licensee PAGEPress, Italy

J. Limnol., 2020; 79(1): 13-29

DOI: 10.4081/jlimnol.2019.1893

\section{INTRODUCTION}

In reservoirs used for public water supply, cyanobacteria may be a serious public health threat (Te and Gin, 2011). This is because they can synthesize and release bioactive secondary metabolites (a.k.a. cyanotoxins) that are hepatotoxic, neurotoxic, cytotoxic, and dermatotoxic (Funari and Testai, 2008; Sierosławska et al., 2010; Buratti et al., 2017).

Several studies have discussed the factors that cause the development of cyanobacterial blooms. Among these factors, high concentrations of nutrients such as nitrogen and phosphorus (Dolman et al., 2012; Figueredo et al., 2016; Chia et al., 2017), high light intensity (Kaebernick and Neilan, 2001; Bittencourt-Oliveira et al., 2010), high temperatures (Paerl and Otten, 2013; Chia et al., 2017), low water transparency, and high $\mathrm{pH}$ values (Gao et al., 2012) stand out. Furthermore, turbulence and stratification (Fortin et al., 2010) and biotic interactions such as competition and herbivory (Wang X. et al., 2010) influence successional processes of cyanobacteria in aquatic ecosystems (Chia et al., 2018). 
Increasing global temperatures and light intensities associated with changing global climatic conditions have been shown to support the excessive proliferation of several noxious bloom forming cyanobacteria, leading to their persistence and wide geographic distribution (Paerl et al., 2011; O'Neil et al., 2012; Paerl and Paul, 2012; Mantzouki et al., 2018). In particular, cyanobacteria appear to be well adapted to take advantage of these changing climatic conditions (Paerl and Huisman 2009).

According to the report of the Intergovernmental Panel on Climate Change (IPCC, 2013), the semi-arid regions will be most affected by the negative effects of climate change. In this region, the dynamics of aquatic ecosystems are strongly affected by the frequent periods of drought, high temperatures, high evaporation rates, and water residence time (Barbosa et al., 2012). Together, these factors cause a reduction in water volume, which leads to higher nutrient concentrations. Climate changes are predicted to increase the frequency and intensity of droughts, which will lead to reductions in water availability in semi-arid regions (Ragab and Prudhomme, 2002; Krol and Bronstert, 2007; Huang et al., 2016). Semi-arid reservoirs appear to be model examples of possible near future effects of climate change on aquatic ecosystems worldwide (Mowe et al., 2015).

Cyanobacterial blooms persist throughout the year in most semi-arid reservoirs and, unfortunately, several of these blooms comprise cyanobacteria species that produce cyanotoxins such as microcystins, cylindrospermopsin, saxitoxins and anatoxins (Bittencourt-Oliveira et al., 2014; Lorenzi et al., 2018; Moura et al., 2018).

The ecological roles of cyanotoxins are not comprehensively understood (Carmichael, 1992; Downing et al., 2015; Omidi et al., 2018), but experimental evidence suggest they lead to the dominance of cyanobacteria and influence successional processes in aquatic ecosystems (Ger et al., 2014; Chia et al., 2018). They act as a defense mechanism against herbivory (Freitas et al., 2014) and as allelochemicals by altering the growth of macrophytes and phytoplankton species during competition for nutrients and light (Rojo et al., 2013; Mohamed, 2017).

Studies have shown that there is a direct relationship between cyanobacteria biomass and cyanotoxin production (Pawlik-Skoworoska and Toporowska, 2016), but cyanotoxins do not always increase with increasing abundance of cyanobacteria (Piccin-Santos and Bittencourt-Oliveira, 2012; Walls et al., 2018). This means that the production of these compounds may have no relation to the ability of cyanobacteria to dominate water bodies.

Most studies on cyanobacteria and cyanotoxins of semi-arid reservoirs have rarely considered how they are influenced by spatial and temporal variations in physicochemical conditions. For example, Lorenzi et al., (2018) showed seasonal and annual changes in cyanotoxins in public supply reservoirs in the semi-arid region of Brazil, but as with the case with other studies, the relationship between physicochemical conditions and biological parameters (cyanobacteria and cyanotoxins) was not described in quantitative terms. Therefore, the objective of the present study was to identify the environmental factors that explain the spatial and temporal variation in cyanobacteria abundance and the concentration of the cyanotoxins; microcystin, saxitoxin and cylindrospermopsin in semi-arid reservoirs. The following hypotheses were tested: i) the largest biovolumes of potential toxin producing cyanobacteria occur when cyanotoxin concentrations are highest; and ii) the environmental factors that explain variations in biovolume of cyanobacteria also explain changes in cyanotoxins concentrations. The results of the present study contribute to the understanding of key factors that control the excessive proliferation of bloom-forming cyanobacteria and their toxins, and will enable the establishment of preventive measures for CyanoHABs in semi-arid public supply reservoirs.

\section{METHODS}

\section{Study area}

The study areas were the Epitácio Pessoa (commonly called the Boqueirão Reservoir) ( $\left.7^{\circ} 28^{\prime} 9^{\prime \prime} \mathrm{S} ; 36^{\circ} 8^{\prime} 2^{\prime \prime} \mathrm{W}\right)$,

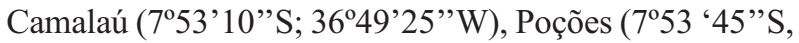
$\left.37^{\circ} 0^{\prime} 50^{\prime \prime} \mathrm{W}\right)$ and Mucutú $\left(7^{\circ} 07^{\prime} 7,8^{\prime \prime} \mathrm{S} ; 36^{\circ} 39^{\prime} 2,3^{\prime \prime} \mathrm{W}\right)$ reservoirs. They are located in the Paraíba River Basin, Paraíba State, Brazil (Fig. 1). The reservoirs provide potable water to 29 cities in Paraiba State and are used for animal watering, recreation, and irrigation.

The region has a tropical climate (BSh) and an annual rainfall of ca. $400 \mathrm{~mm}$ in the driest areas (Alvares et al., 2013). The highest precipitation is recorded between February and May (Araújo et al., 2009), but a prolongated drought occurred between 2014 and 2017, when rainfall was below the historical average of the region (Walter $e t$ al., 2018; Jovem-Azevêdo et al., 2019). This prolonged drought resulted in a drastic reduction in the water volume of the reservoirs; consequently, water supply shortages (Martins et al., 2015; Walter et al., 2018).

From April 2017, the reservoirs Boqueirão, Camalaú and Poções received water from the São Francisco River. The Brazilian government project named the "São Francisco River Integration Project", fed more than 700 kilometers of concrete channels in two major axes (north and east) with water from São Francisco River passing through Pernambuco, Paraíba, Ceará and Rio Grande do Norte states. 


\section{Sampling and data analysis}

Samplings were conducted in October 2016 and February and June of 2017 (i.e. the dry season of the region), at three locations in the reservoirs, between the dam and the point of entry of the Paraíba River, namely: site 1, point of entry of the Paraíba River to the reservoirs; site 2, region between the dam and the point of entry of the Paraíba River; and site 3, located on the dam (Fig. 1). Samples (32 L) were collected under the water surface with the aid of a bucket for nutrients, chlorophyll-a, cyanobacteria, and cyanotoxins analyses.

\section{Climatic variables, abiotic variables, and chlorophyll-a}

Data on water volume of the reservoirs and average precipitation during the sampling dates were obtained from the Agência Executiva de Gestão das Águas (AESA; Paraíba State).

Water temperature $\left({ }^{\circ} \mathrm{C}\right), \mathrm{pH}$, and turbidity (NTU) were measured in situ with the HORIBA $^{\odot}$ U-50 multi- parameter probe. Water transparency was determined using the Secchi disk.

Samples for nutrient analysis and chlorophyll-a were stored in plastic bottles and transported on ice to the laboratory. The concentration of ammonia $\left(\mathrm{NH}_{4}-\mathrm{N}\right)$, nitrate $\left(\mathrm{NH}_{3}-\mathrm{N}\right)$, nitrite $\left(\mathrm{NH}_{2}-\mathrm{N}\right)$, soluble reactive phosphorus (SRP), and total phosphorus (TP) were measured according to the techniques described in APHA (2012). Dissolved inorganic nitrogen (DIN) content was determined by summing the concentrations of $\mathrm{NH}_{4}-\mathrm{N}, \mathrm{NH}_{3}-\mathrm{N}$ and $\mathrm{NH}_{2}-\mathrm{N}$. Chlorophyll-a was extracted with $96 \%$ ethanol per the method of Jespersen and Christoffersen (1987) and measured spectrophotometrically (Lorenzen, 1967).

Total phosphorus and chlorophyll-a data were used to calculate the Trophic State Index (TSI) as described by Carlson (1977) and modified for tropical environments by Toledo Jr. et al., (1983). The trophic classification followed the criterion: oligotrophic TSI $<44$, mesotrophic $44<$ TSI $>54$ and eutrophic TSI $>54$.

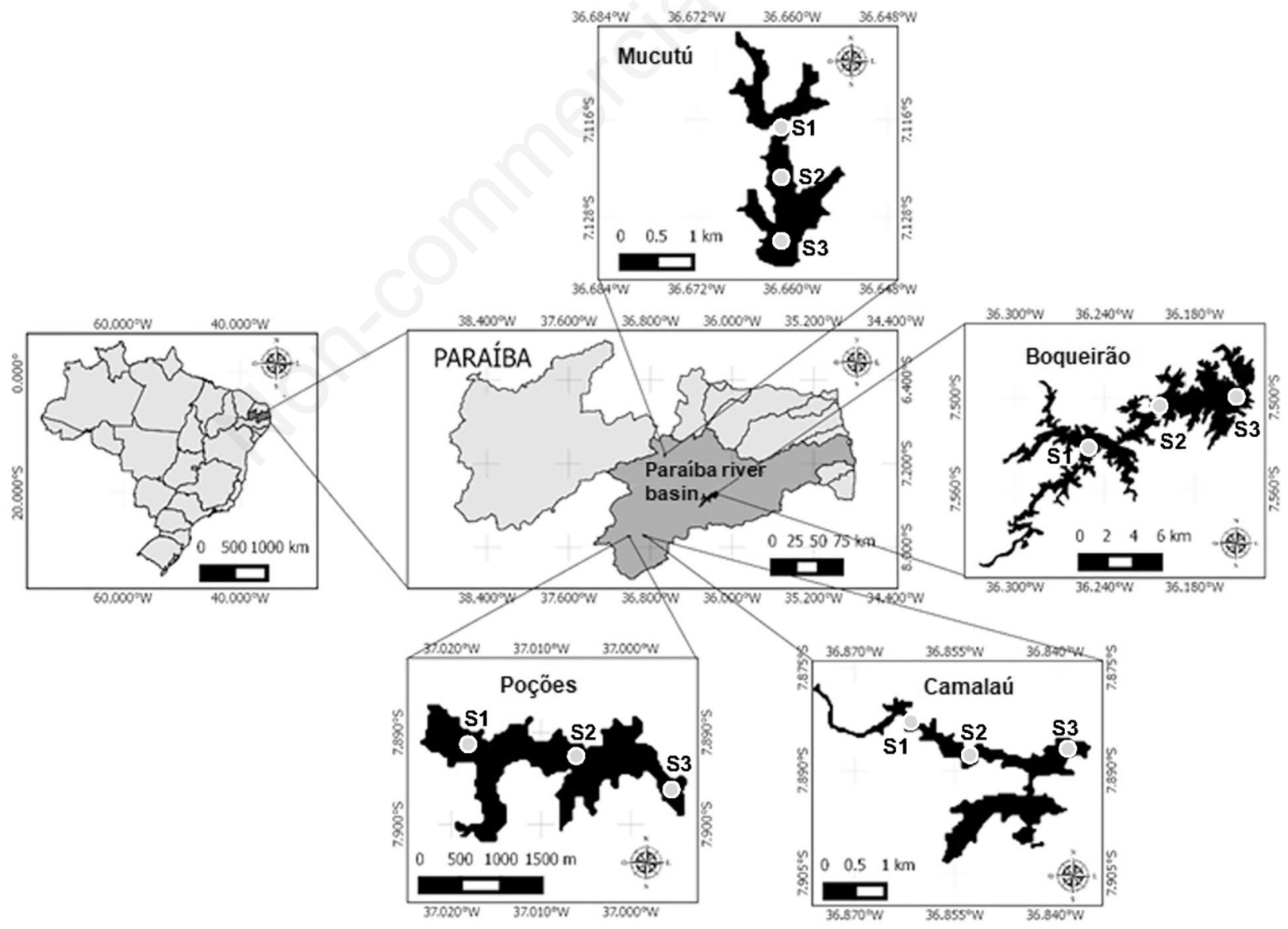

Fig. 1. Location of Boqueirão, Camalaú, Mucutú and Poções reservoirs in the State of Paraíba, Brazil. •, Sampling sites; S1, sampling site 1 ; S2, sampling site 2; S3, sampling site 3. 


\section{Cyanobacteria biovolume}

Samples for analysis of cyanobacteria were collected directly from the water, stored in amber flasks and fixed with $1 \%$ Lugol. Semipermanent slides of cyanobacterial samples were prepared, viewed under a Zeiss Axioskop 40 optical microscope (Carl Zeiss, Jena, Germany), and the taxa identified using identification keys provided by Komárek and Anagnostidis (1989, 1999, 2005), Komárek et al. (2002), and Komárek (2013). Quantitative analysis of cyanobacteria was performed using an inverted microscope (Zeiss Axiovert $40^{\circ} \mathrm{C}$ ) at $400 \mathrm{X}$ magnification (Uthermöhl, 1958). At least 400 individuals of the most abundant species or 100 fields per sample were enumerated to minimize count errors. Density (individuals $\mathrm{mL}^{-1}$ ) was obtained using the formula described by Ross (1979) and the biovolume $\left(\mathrm{mm}^{3} \mathrm{~L}^{-1}\right)$ was estimated by multiplying the density of the species by the average volume of the cells ( $\sim 20$ individuals). The volume of the cell was calculated from geometric models close to the shape of the species - spheres, cylinders, cones, parallelepipeds, pyramids, ellipsoids and others as described by Hillebrand et al. (1999).

\section{Cyanotoxins}

For the analysis of cyanotoxin concentrations, thirty liters of the water from the reservoirs (per sampling station) were filtered and concentrated through a plankton net $(20 \mu \mathrm{m}$ mesh size), stored in $250 \mathrm{~mL}$ bottles, and transported on ice to the laboratory in a styrofoam box.

The total concentrations $\left(\mu \mathrm{g} \mathrm{L}^{-1}\right)$ of microcystin, saxitoxin and cylindrospermopsin were determined by the Enzyme-Linked Immuno Sorbent Assay (ELISA) method using kits an Abraxis plate (Warminster, $\mathrm{Pa}$ ) specific to each toxin, per manufacturer's instruction. To extract the toxin from the cells, three freeze/thaw cycles were carried out on the samples at $40^{\circ} \mathrm{C}$. The absorbance of the color reaction of the ELISA runs was measured with an ASYS A-5301 microplate reader (ASYS Hitech GmbH, Eugendorf, Austria).

\section{Statistical analysis}

In order to test for significant differences in the physical and chemical variables, cyanobacteria biovolumes, and cyanotoxin concentrations between the months (October, February, and June) and sampling sites, a Linear Mixed Effects Model was used. This was followed by the Holm-Sidak post hoc test to separate means that were significantly different. The normality and homoscedasticity of the data were evaluated via the Kolmogorov-Smirnov and Mauchly's Sphericity tests, respectively. Where Sphericity was violated, the Greenhouse-Geisser and Huynh-Feldt corrections were employed.
The Pearson correlation test (r) was applied to verify the correlation between the analyzed cyanotoxins and potential cyanotoxin-producing species. The potential species that produce microcystin, saxitoxin, and cylindrospermopsin were determined according to Bernard et al. (2016).

Redundancy analysis (RDA) was performed to identify the relationship between physical and chemical variables and cyanobacteria and cyanotoxins. The criterion for selection of the RDA was based on the length of the axes of the Detrended Correspondence Analysis (DCA), which ratifies the performance of this analysis when the length of axis 1 is lower than that of axis 3 (Ter Braak and Prentice, 1988). To test if the RDA model was significant, a factorial ANOVA was run.

Two RDAs were performed, one containing cyanobacteria as the dependent data and the other cyanotoxins. The matrix with the abiotic variables was standardized using Standard Deviation. To identify the abiotic variables that made independent and significant contributions to the variation of cyanobacteria and cyanotoxins, selection of variables was performed stepwise using permutation tests, and then selection by variance inflation factor (VIF) from the inclusion of variables with $\mathrm{VIF}<20$. In the cyanobacteria data matrix, only species with biovolumes equal to or greater than $1 \%$ of the total phytoplankton biovolume were included, and the data $\log$ transformed $(\log [\mathrm{x}+1])$.

Correlation and Redundancy analyses were performed at a significance level of 5\% using the R software for Windows. Linear Mixed Effects Model was performed using IBM SPSS version 24 for MacOS.

\section{RESULTS}

\section{Abiotic variables and trophic state index}

During the study period, it rained only in June 2017 at Boqueirão, Camalaú and Poções reservoirs. Maximum rainfall $(39.10 \mathrm{~mm})$ was recorded in Poções Reservoir (Fig. 2). The volume of water in these reservoirs was $c a$. 6\% in October 2016, followed by an increase in June 2017 to the highest value of $14.90 \%$ in Poções Reservoir (Fig. 2 A,B,D). In the Mutucú Reservoir, rainfall occurred from February $2017(17.4 \mathrm{~mm})$, but its water volume continued to decline in the following months, reaching $0.65 \%$ in June 2017 (Fig. 2C).

The TSI varied between 55 and 73 in all the reservoirs, which led to their classification as eutrophic (Fig. 2). Changes in physical and chemical parameters were significantly different $(\mathrm{P}<0.05)$ between the sampled months, while those observed between the sampling sites were not (Tab. 1). In the Boqueirão Reservoir, water temperature not significantly $(\mathrm{P}=0.354)$ higher in 
February 2017, while water transparency $(\mathrm{P}=0.01)$ and $\mathrm{pH}$ $(\mathrm{P}=0.002)$ were lowest in June 2017. Similarly, the highest turbidity $(p>0.05)$, nitrate $(p=0.039)$, orthophosphate $(\mathrm{P}>0.05)$, and total phosphorus $(\mathrm{P}>0.05)$ levels were recorded in June 2017 (Tab. 1). In June 2017, the Camalaú Reservoir had the lowest water transparency $(\mathrm{P}=0.001)$ and $\mathrm{pH}(\mathrm{P}<0.001)$, while nitrate $(\mathrm{P}=0.014)$ and total phosphorus $(\mathrm{P}=0.043)$ concentrations were highest in the same month (Tab. 1).

Physicochemical conditions such as water temperature ( $\mathrm{P}=0.022)$, turbidity $(\mathrm{P}<0.001)$, and total phosphorus $(\mathrm{P}=0.002)$ were highest in Poções reservoir in February 2017 , while water transparency was lowest $(\mathrm{p}=0.004)$ (Tab. 1). In addition, in June 2017, the lowest pH was recorded $(\mathrm{P}<0.001)$ in Poções reservoir. In Mucutú Reservoir, in June 2017, the highest turbidity $(\mathrm{P}=0.011)$, ammonia $(\mathrm{P}<0.001)$, nitrite $(\mathrm{P}>0.05)$, DIN $(\mathrm{P}<0.001)$, and total phosphorus $(\mathrm{P}<0.016)$ levels were found (Tab. 1). The highest water temperature was recorded in Februrary $2017(\mathrm{P}=0.03)$ in Mucutú reservoir.

\section{Cyanobacteria}

Twenty-four species of cyanobacteria were identified in the reservoirs studied, out of which 10 are potential toxin producers. Specifically, seven of the species were potential producers of microcystins, four of saxitoxins, and two of cylinderspermopsin (Tab. 2).

The total biovolume of cyanobacteria ranged from 0.03 to $16.57 \times 10^{2} \mathrm{~mm}^{3} \mathrm{~L}^{-1}$ in Boqueirão reservoir, 0.01 to $23.77 \times 10^{2} \mathrm{~mm}^{3} \mathrm{~L}^{-1}$ in Camalaú reservoir, 0.69 to 40.15 $\mathrm{x} 10^{2} \mathrm{~mm}^{3} \mathrm{~L}^{-1}$ in Mucutú reservoirs and 0.02 to 310.76 $x 10^{2} \mathrm{~mm}^{3} \mathrm{~L}^{-1}$ in Poções reservoir (Tab. 3). A significant increase in total cyanobacterial biomass was recorded in February 2017 in Camalaú $(\mathrm{p}=0.003)$ and Mucutú $(\mathrm{P}=0.000)$ reservoirs. Cyanobacteria biomass data revealed that Coelomorum tropicale had the highest biomass contribution in Poções Reservoir, and Dolichospermum solitarium and Cylindrospermopsis raciborskii in Camalaú Reservoir (Fig. 3).

The RDA showed that the influence of abiotic
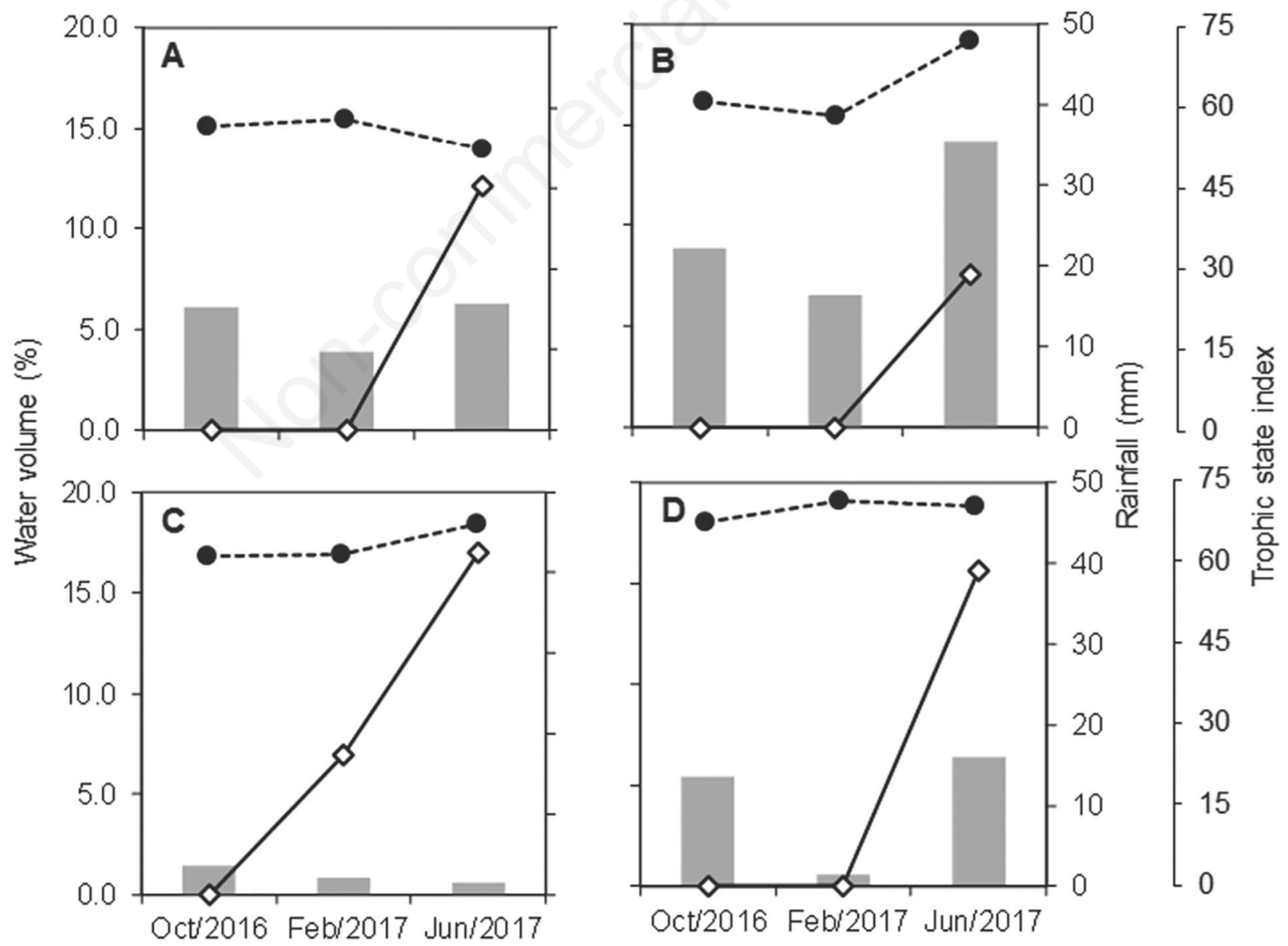

Fig. 2. Rainfall, water volume, and trophic state index in the Boqueirão (A), Camalaú (B), Mucutú (C), and Poções (D) reservoirs in October 2016 and February and June 2017. - , water volume; - - -, rainfall; --•--, trophic state index. 
Tab. 1. Physical and chemical characteristics of Boqueirão, Camalaú, Poções, and Mucutú reservoirs.

\begin{tabular}{|c|c|c|c|c|c|c|c|c|c|c|}
\hline Reservoirs/variables & $\begin{array}{l}\text { Temp } \\
\left(C^{\circ}\right)\end{array}$ & $\begin{array}{l}\text { Secchi } \\
(\mathrm{cm})\end{array}$ & $\begin{array}{l}\text { Turb } \\
\text { (UNT) }\end{array}$ & $\mathrm{pH}$ & $\begin{array}{l}\mathrm{N}-\mathrm{NH}_{4} \\
\left(\mu \mathrm{g} \mathrm{L}^{-1}\right)\end{array}$ & $\begin{array}{l}\mathrm{N}-\mathrm{NH}_{2} \\
\left(\mu \mathrm{g} \mathrm{L}^{-1}\right)\end{array}$ & $\begin{array}{l}\mathrm{N}-\mathrm{NH}_{3} \\
\left(\mu \mathrm{g} \mathrm{L}^{-1}\right)\end{array}$ & $\begin{array}{c}\text { DIN } \\
\left(\mu \mathrm{g} \mathrm{L}^{-1}\right)\end{array}$ & $\begin{array}{c}\text { SPR } \\
\left(\mu \mathrm{g} \mathrm{L}^{-1}\right)\end{array}$ & $\begin{array}{c}\text { TP } \\
\left(\mu g \mathrm{~L}^{-1}\right)\end{array}$ \\
\hline \multicolumn{11}{|l|}{ Boqueirão reservoir } \\
\hline \multicolumn{11}{|l|}{ October/2016 } \\
\hline S1 & 24.57 & 1.39 & 18.50 & 8.91 & 248.00 & 5.60 & 96.34 & 349.94 & 33.00 & 160.33 \\
\hline $\mathrm{S} 2$ & 24.92 & 1.50 & 16.80 & 8.54 & 12.69 & 0.00 & 25.43 & 38.12 & 43.00 & 120.00 \\
\hline S3 & 24.57 & 1.08 & 7.65 & 8.64 & 198.2 & 2.24 & 24.22 & 224.66 & 13.00 & 53.66 \\
\hline \multicolumn{11}{|l|}{ February/2017 } \\
\hline $\mathrm{S} 1$ & 25.95 & 1.40 & 2.36 & 8.47 & 23.97 & 0.00 & 33.91 & 57.88 & 3.00 & 43.66 \\
\hline S2 & 26.57 & 1.19 & 36.10 & 8.52 & 13.39 & 15.67 & 8.48 & 37.54 & 28.00 & 33.66 \\
\hline S3 & 26.23 & 1.78 & 18.50 & 8.49 & 6.34 & 7.84 & 14.53 & 28.71 & 28.00 & 60.33 \\
\hline \multicolumn{11}{|l|}{ June/2017 } \\
\hline $\mathrm{S} 1$ & 24.71 & 0.40 & 194.00 & 7.45 & 47.24 & 25.75 & 193.79 & 266.78 & 83.00 & 300.33 \\
\hline $\mathrm{S} 2$ & 24.80 & 0.45 & 9.50 & 7.56 & 43.71 & 24.63 & 218.01 & 286.35 & 93.00 & 340.33 \\
\hline S3 & 25.14 & 1.10 & 228.00 & 7.91 & 40.19 & 4.48 & 69.04 & 113.71 & 3.00 & 80.33 \\
\hline \multicolumn{11}{|l|}{ Camalaú reservoir } \\
\hline \multicolumn{11}{|l|}{ October/2016 } \\
\hline $\mathrm{S} 1$ & 24.81 & 1.46 & 19.00 & 9.20 & 64.87 & 97.39 & 190.16 & 352.42 & 153.00 & 273.66 \\
\hline $\mathrm{S} 2$ & 24.52 & - & 34.80 & 8.80 & 11.98 & 12.24 & 24.22 & 48.44 & 23.00 & 304.00 \\
\hline $\mathrm{S} 3$ & 23.86 & - & 29.70 & 8.69 & 14.80 & 0.00 & 53.29 & 68.09 & 18.00 & 67.00 \\
\hline \multicolumn{11}{|l|}{ February/2017 } \\
\hline $\mathrm{S} 1$ & 26.2 & 0.65 & 136.00 & 8.97 & 9.87 & 4.48 & 13.22 & 27.57 & 38.00 & 57.00 \\
\hline $\mathrm{S} 2$ & 25.53 & 0.78 & 116.00 & 8.92 & 2.82 & 14.55 & 10.9 & 28.27 & 28.00 & 57.00 \\
\hline $\mathrm{S} 3$ & 25.13 & 0.81 & 37.40 & 8.55 & 7.75 & 5.60 & 6.05 & 19.4 & 28.00 & 60.33 \\
\hline \multicolumn{11}{|l|}{ June/2017 } \\
\hline $\mathrm{S} 1$ & 22.79 & 0.34 & 178.00 & 7.64 & 47.94 & 42.54 & 171.99 & 262.47 & 73.00 & 633.66 \\
\hline S2 & 24.65 & 0.34 & 90.00 & 7.42 & 25.38 & 3.36 & 164.72 & 193.46 & 143.00 & 370.33 \\
\hline $\mathrm{S} 3$ & 25.09 & 0.34 & 79.80 & 7.61 & 46.53 & 0.00 & 171.99 & 218.52 & 43.00 & 253.66 \\
\hline \multicolumn{11}{|l|}{ Mucutú reservoir } \\
\hline \multicolumn{11}{|l|}{ October/2016 } \\
\hline $\mathrm{S} 1$ & 23.6 & 0.24 & 29.10 & 8.26 & 110.70 & 5.60 & 60.65 & 176.95 & 28.00 & 180.33 \\
\hline $\mathrm{S} 2$ & 19.7 & 0.63 & 6.30 & 6.70 & 14.78 & 4.48 & 24.89 & 44.15 & 38.00 & 98.00 \\
\hline $\mathrm{S} 3$ & 25.07 & 0.50 & 4.40 & 8.36 & 16.21 & 4.48 & 29.07 & 49.76 & 63.00 & 173.66 \\
\hline \multicolumn{11}{|l|}{ February/2017 } \\
\hline $\mathrm{S} 1$ & 25.3 & 0.27 & 136.00 & 7.99 & 703.21 & 0.00 & 10.9 & 714.11 & 3.00 & 157.00 \\
\hline $\mathrm{S} 2$ & 25.51 & 0.31 & 56.00 & 7.61 & 626.15 & 3.36 & 8.48 & 637.99 & 18.00 & 133.66 \\
\hline $\mathrm{S} 3$ & 25.71 & 0.31 & 62.80 & 7.73 & 731.21 & 0.00 & 4.84 & 736.05 & 58.00 & 167.00 \\
\hline \multicolumn{11}{|l|}{ June/2017 } \\
\hline $\mathrm{S} 1$ & 23.16 & 0.23 & 231.00 & 7.41 & 1107.05 & 23.51 & 31.49 & 1162.05 & 193.00 & 423.65 \\
\hline $\mathrm{S} 2$ & 23.61 & 0.23 & 188.00 & 7.67 & 1170.51 & 23.51 & 41.18 & 1235.20 & 183.00 & 377.00 \\
\hline S3 & 23.85 & 0.23 & 192.00 & 7.57 & 906.97 & 24.63 & 42.39 & 973.99 & 188.00 & 397.00 \\
\hline \multicolumn{11}{|l|}{ Poções reservoir } \\
\hline \multicolumn{11}{|l|}{ October/2016 } \\
\hline $\mathrm{S} 1$ & 25.97 & 0.47 & 48.90 & 7.60 & 456.00 & 0.00 & 20.59 & 476.59 & 5.00 & 318.00 \\
\hline $\mathrm{S} 2$ & 24.8 & 0.39 & 54.80 & 8.39 & 24.67 & 8.96 & 47.24 & 80.87 & 38.20 & 207.00 \\
\hline $\mathrm{S} 3$ & 25.66 & 0.41 & 50.50 & 8.28 & 50.60 & 14.10 & 80.60 & 145.30 & 158.00 & 638.78 \\
\hline \multicolumn{11}{|l|}{ February/2017 } \\
\hline $\mathrm{S} 1$ & 29.65 & 0.10 & 325.00 & 8.46 & 14.10 & 11.19 & 16.96 & 42.25 & 913.00 & 883.66 \\
\hline $\mathrm{S} 2$ & 29.75 & 0.16 & 394.00 & 8.70 & 62.06 & 320.15 & 218.01 & 600.22 & 633.00 & 1070.33 \\
\hline S3 & 27.12 & 0.16 & 297.00 & 8.71 & 239.74 & 226.12 & 186.52 & 652.38 & 638.00 & 870.33 \\
\hline \multicolumn{11}{|l|}{ June/2017 } \\
\hline $\mathrm{S} 1$ & 25.51 & 0.41 & 12.50 & 7.43 & 98.71 & 53.73 & 147.76 & 262.47 & 133.00 & 377.00 \\
\hline $\mathrm{S} 2$ & 25.14 & 0.41 & 190.00 & 7.35 & 45.83 & 10.07 & 125.96 & 193.46 & 103.00 & 243.66 \\
\hline $\mathrm{S} 3$ & 24.37 & 0.41 & 151.00 & 7.23 & 86.02 & 8.96 & 140.50 & 181.86 & 153.00 & 443.66 \\
\hline
\end{tabular}

Temp, water temperature; Secchi, water transparency; Turb, turbidity; NH4-N, ammonia; NH2-N, nitrite; NH3-N, nitrate; DIN, dissolved inorganic nitrogen; SRP, soluble reactive phosphorus; TP, total phosphorus; S1, sampling site 1; S2, sampling site 2; S3, sampling site 3. 
variables on cyanobacteria species was significant $\left(\mathrm{F}_{\text {Boqueirão }}=2.76, \mathrm{P}=0.003 ; \mathrm{F}_{\text {Camalau }}=2.47, \mathrm{P}=0.003 ; \mathrm{F}_{\text {Mucutu }}=\right.$ 8.48, $\left.\mathrm{P}=0.005 ; \mathrm{F}_{\text {Poç̃es }}=3.46 ; \mathrm{P}=0.007\right)$. In Boqueirão Reservoir, the RDA explainability was $59.78 \%$. Water transparency had the most significant positive contribution to axis 1 , where it grouped D. solitarium, Eucapis densa, Plankthotrix isothrix, Pseudanabaena catenata, P. galeata, Spirulina subsalsa, and Synechocystis aquatilis in October 2016 and February 2017 (Fig. 4A).

In the Camalaú Reservoir, the proportion explained by the RDA was $43.45 \%$, where water volume had a positive relationship with axis 1 and was grouped with Aphanocaspa annulata, Chroococcus dispersus, E. densa, and Merismopedia minima in June 2017. On the other hand, water transparency had a negative association with axis 1 and was grouped with Aphanocaspa delicatissima, Chroococcus minutus, and Dolichospermim circinale in October 2016 (Fig. 4B). The second axis of the RDA for Camalaú reservoir grouped Cuspidothrix tropicalis, Cylindrospermopsis raciborskii, Plankthotrix agardhii, $P$. galeata, and P. isothrix in February 2017.

The explanability of the RDA for Mucutú Reservoir was $54.79 \%$, where SRP had a positive relationship with Geitlerinema amphibium in June 2017 (Fig. 4C). In the Poções Reservoir, the proportion explained by the RDA was $47.74 \%$, and TP was the explanatory variable having a positive contribution to axis 1 and a negative relationship with $A$. annulata, Aphanocapsa incerta, and C. dispersus in June 2017 (Fig. 4D).

Tab. 2. Species of cyanobacteria identified in the studied reservoirs.

\begin{tabular}{|c|c|c|c|c|c|}
\hline \multirow[t]{2}{*}{ Species } & \multicolumn{3}{|c|}{ Reservoirs } & \multirow[b]{2}{*}{ Poções } & \multirow{2}{*}{$\begin{array}{l}\text { Potencial } \\
\text { cyanotoxins } \\
\text { producers }\end{array}$} \\
\hline & Boqueirão & Camalaú & Mucutú & & \\
\hline \multicolumn{6}{|l|}{ Chroococcales } \\
\hline Chroococcus dispersus & $\mathrm{x}$ & $\mathrm{x}$ & & $\mathrm{x}$ & - \\
\hline Chroococcus limneticus & $\mathrm{x}$ & a & & & - \\
\hline Chroococcus minutus & & $\mathrm{x}$ & & & - \\
\hline Microcystis aeruginosa & & $\mathrm{x}$ & & & Mic \\
\hline \multicolumn{6}{|l|}{ Oscillatoriales } \\
\hline Geitlerinema amphibium & & & $\mathrm{x}$ & & Sax \\
\hline Planktothrix agardhii & $\mathrm{x}$ & $\mathrm{x}$ & $\mathrm{x}$ & & Mic \\
\hline Planktothrix isotrix & $\mathrm{x}$ & $\mathrm{x}$ & $\mathrm{x}$ & & Mic \\
\hline Spirulina subsalsa & $\mathrm{x}$ & & & & - \\
\hline \multicolumn{6}{|l|}{ Nostocales } \\
\hline Aphanizomenon gracile & $\mathrm{x}$ & & & & Cyl/Sax \\
\hline Cylindrospermopsis raciborskii & & $\mathrm{x}$ & & & Cyl/Sax \\
\hline Cuspidothrix tropicalis & & $\mathrm{x}$ & $\mathrm{x}$ & & - \\
\hline Dolichospermum solitarium & $\mathrm{x}$ & $\mathrm{x}$ & $\mathrm{x}$ & & - \\
\hline D. circinale & & $\mathrm{x}$ & & & $\mathrm{Mic} / \mathrm{Sax}$ \\
\hline \multicolumn{6}{|l|}{ Synechococcales } \\
\hline Aphanocapsa annulata & $\mathrm{x}$ & $\mathrm{x}$ & & $\mathrm{x}$ & - \\
\hline Aphanocapsa delicatissima & & $\mathrm{x}$ & & & - \\
\hline Aphanocapsa incerta & $\mathrm{x}$ & $\mathrm{x}$ & & $\mathrm{x}$ & - \\
\hline Coelomoron tropicale & & $\mathrm{x}$ & & $\mathrm{x}$ & - \\
\hline Eucapis densa & $\mathrm{x}$ & $\mathrm{x}$ & $\mathrm{x}$ & $\mathrm{x}$ & - \\
\hline Limnococcus limneticus & $\mathrm{x}$ & & & $\mathrm{x}$ & - \\
\hline Merismopedia glauca & $\mathrm{x}$ & & & & - \\
\hline Merismopedia tenuissima & & & & $\mathrm{x}$ & Mic \\
\hline Pseudanabaena catenata & $\mathrm{x}$ & & $\mathrm{x}$ & & Mic \\
\hline Pseudanabaena galeata & $\mathrm{x}$ & $\mathrm{x}$ & $\mathrm{x}$ & & Mic \\
\hline Synechocystis aquatilis & $\mathrm{x}$ & $\mathrm{x}$ & & & - \\
\hline Species richness & 15 & 16 & 8 & 7 & \\
\hline
\end{tabular}

Mic, microcystins; Sax, saxitoxins; Cyl, cylindrospermopsin; -, there is no record of toxicity. 


\section{Cyanotoxins}

Microcystin was detected throughout the investigation in Boqueirão, Camalaú, Mucutú and Poções reservoirs, with the exception of the samples obtained in February 2017 from Camalaú Reservoir (Fig. 5). Saxitoxin was also present in all the reservoirs, but less frequently than microcystin, while cylindrospermopsin was only recorded in Camalaú Reservoir in February 2017. The maximum concentrations recorded were $2.28,1.98$ and $2.89 \mu \mathrm{g} \mathrm{L}^{-1}$ for total microcystins, total saxitoxins and total cylindrospermopsins, respectively.

The PCA for potential toxic cyanobacteria and cyanotoxins of Boqueirão Reservoir indicated that microcystin was positively related to $P$. galeata, $P$. agardhii and $P$. isothrix, while saxitoxin was positively associated with Synechocystis aquatilis and Aphanizomenon gracile. In the Camalaú Reservoir, microcystin and cylindrospermopsin had a positive relationship with $P$. galeata, $P$. agardhii, $P$. isothrix and C. raciborskii, while saxitoxin was positively correlated with D. circinale, Dolichospermum solitarium and Microcystis aeruginosa. In the Mucutú Reservoir, microcystin had a positive relationship with $P$. galeata, $P$. agardhii, and $P$. isothrix, while saxitoxin was related to G. amphibium. In Poções Reservoir, the only potential toxin producing species identified was Merismopedia tenuissima, which also had a positive relationship with saxitoxin (Fig. 6).

The RDA for the influence of the abiotic variables on the cyanotoxins was significant $\left(\mathrm{F}_{\text {Boqueirão }}=8.53, \mathrm{P}=0.045\right.$; $\mathrm{F}_{\text {Camalaú }}=18.15, \mathrm{P}=0.004 ; \mathrm{F}_{\text {Mucutú }}=5.17, \mathrm{P}=0.040 ; \mathrm{F}_{\text {Poções }}=$ $5.65, \mathrm{P}=0.043$ ). Transparency, TP, SRP and water volume significantly influenced the cyanotoxin concentrations of Boqueirão, Camalaú, Mucutú and Poções, respectively
(Fig. 7). However, no clear pattern was found in the distribution of cyanotoxins, since they remained close to the origin of the ordination.

\section{DISCUSSION}

In this study, the cyanotoxins, microcystin and saxitoxin were detected in all the investigated reservoirs, while cylinderspermopsin was limited to a single reservoir (Camalaú Reservoir). This is the first record of cylindrospermopsin in a reservoir in the State of Paraíba, Northeast of Brazil. To date, most cylindrospermopsin detections have been in the State of Pernambuco in the northeast of Brazil (Bittencourt-Oliveira et al., 2011; Lorenzi et al., 2018).

Several of the identified potential toxin producing species had a linear relationship with the presence of specific cyanotoxins and these results corroborate with those of other studies (Costa et al., 2006; Yang et al., 2006; Naselli $\square$ Flores et al., 2007; Sinang et al., 2015; Lorenzi et al., 2015; Lorenzi et al., 2018). In contrast to known hypotheses, and field and experimental evidence (Dolman et al., 2012; Monchamp et al., 2014), saxitoxin was detected in the absence of known potential producers of this bioactive secondary metabolite in Poções Reservoir, which probably indicates the presence of yet to be identified producers of this toxin. These results suggest that using only the identification of potential toxin-producing species as an indicator of the presence of cyanotoxins in monitoring programs for water quality assessment can be problematic and inadequate.

Another possible explanation for the detection of saxitoxins in the absence of potential producers may be that sampling was performed after the breakdown of

Tab. 3. Biovolume of cyanobacteria $\left(\times 10^{2} \mathrm{~mm}^{3} \mathrm{~L}^{-1}\right)$ in Boqueirão, Camalaú, Mucutú, and Poções reservoirs, in October 2016, and February and June 2017.

\begin{tabular}{|c|c|c|c|c|}
\hline \multirow[t]{2}{*}{ Months and Sites } & \multicolumn{4}{|c|}{ Reservoirs } \\
\hline & Boqueirão & Camalaú & Mucutú & Poções \\
\hline \multicolumn{5}{|l|}{ October/2016 } \\
\hline $\mathrm{S} 1$ & 0.14 & 1.14 & 40.15 & 0.02 \\
\hline S2 & 9.14 & 1.33 & 5.02 & 0.21 \\
\hline S3 & 16.57 & 0.68 & 1.47 & 1.79 \\
\hline \multicolumn{5}{|l|}{ February/2017 } \\
\hline $\mathrm{S} 1$ & 5.46 & 18.48 & 0.69 & 310.76 \\
\hline S2 & 1.41 & 23.77 & 1.12 & 127.70 \\
\hline S3 & 12.49 & 14.44 & 6.63 & 39.03 \\
\hline \multicolumn{5}{|l|}{ June/2017 } \\
\hline $\mathrm{S} 1$ & 0.03 & 0.01 & 3.27 & 0.07 \\
\hline S2 & 2.68 & 0.14 & 2.32 & 0.23 \\
\hline $\mathrm{S} 3$ & 9.50 & 0.01 & 9.80 & 0.07 \\
\hline Total biovolume & $6.38 \pm 5.88$ & $6.66 \pm 9.48$ & $7.83 \pm 12.48$ & $53.32 \pm 105.37$ \\
\hline
\end{tabular}

S1, sampling site 1; S2, sampling site 2; S3, sampling site 3. 
blooms of known producers. This is because these compounds tend to remain chemically stable for weeks in the environment at higher concentrations after cell lysis, making it impossible for the detection of potential toxin producing species (Jones and Orr, 1994; Lahti, 1997; Chorus and Bartram, 1999; Funari and Testai, 2008).

A

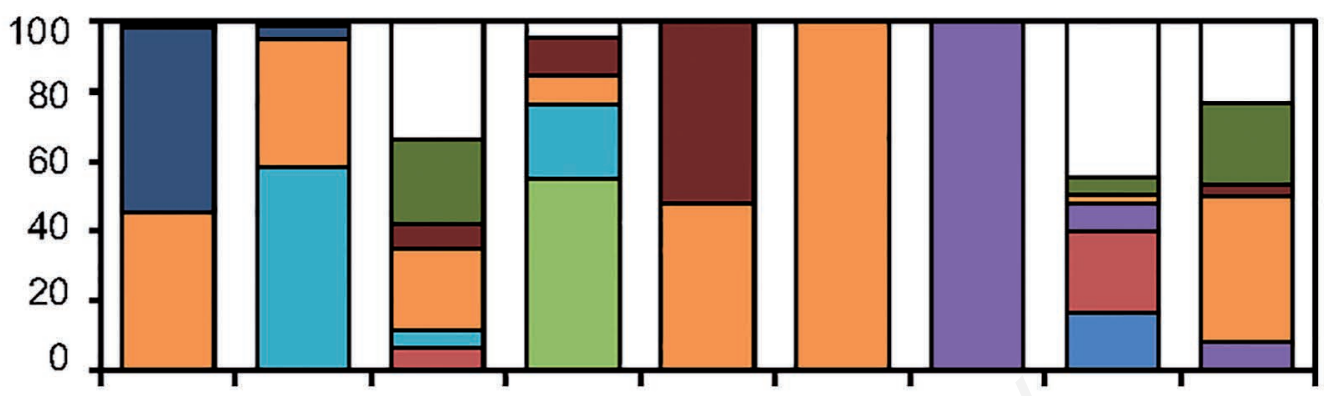

B

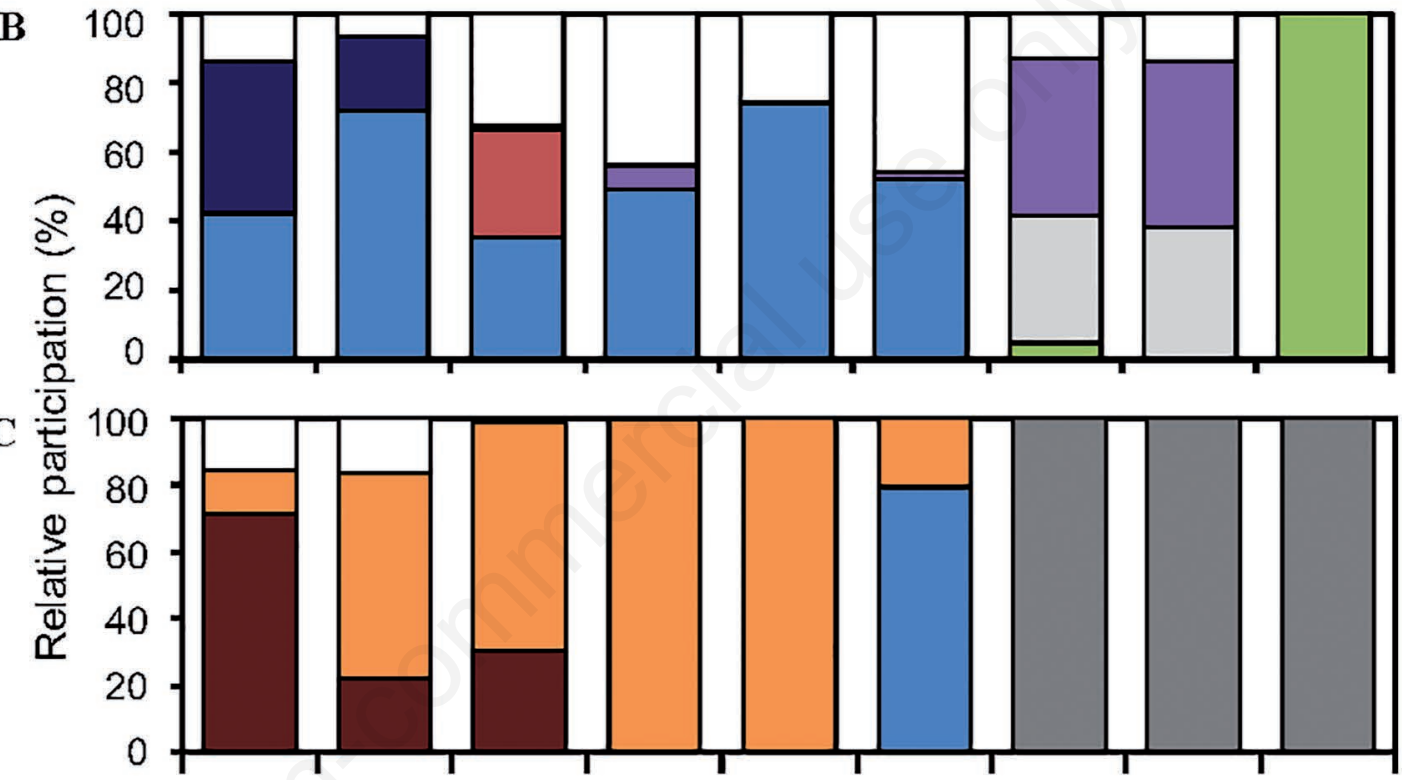

D

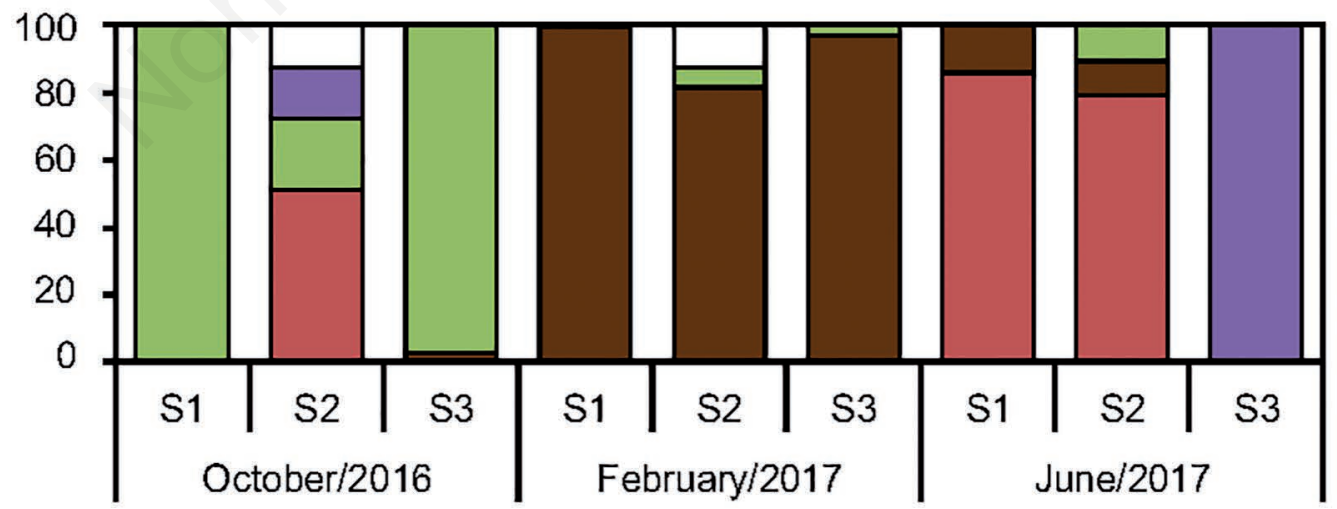

Fig. 3. Relative abundance of Cyanobacteria in the Boqueirão (A), Camalaú (B), Mucutú (C) and Poções (D) reservoirs in October 2016 and February and June 2017. Species with biovolume equal to or less than $1 \%$ of the total biovolume of Cyanobacteria were

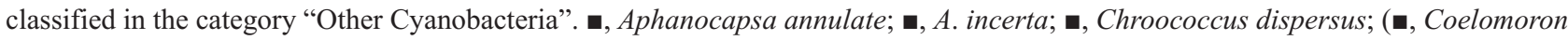
tropicale; $\mathbf{\square}$, Dolichospermum circinale; $\mathbf{\square}$, D. solitatium; $\mathbf{\square}$, Eucapsis densa; $\mathbf{\square}$, Merismopedia minima; $\mathbf{\square}$, Microcystis aeruginosa; $\mathbf{\square}$ Planktothrix isothrix; - P. agardhii; $\mathbf{\square}$, Pseudanabaena catenata; $\square$, Other Cyanobacteria. "Other Cyanobacteria” in the Boqueirão Reservoir were Chroococcus dispersus, Eucapis densa, and Spirulina subsalsa; in the Camalaú Reservoir were C. dispersus, C. minutus, Coelomoron tropicalis and E. densa; in the Mucutú Reservoir was E. densa; and in the Poções Reservoir were C. tropicale, C. disperses, and E. densa. S1, sampling site 1; S2, sampling site 2; S3, sampling site 3. 
Potential microcystin-producing species had the highest relative abundance in the studied reservoirs, which correlated with the frequent detection of the cyanotoxin. This result is consistent with the assertion that this is the most common and frequently detected cyanotoxin in lakes and reservoirs (Mowe et al., 2015; Paerl and Otten, 2016). However, as reported by Merel et al., (2013), it can not be ruled out that the high frequency of microcystin detection in water bodies published is because they are much more studied and monitored than other cyanotoxins.
Therefore, it is important to monitor other cyanotoxins, in addition to microcystins, to comprehensively determine the risk of cyanobacterial metabolites in aquatic ecosystems.

Microcystin production has been frequently associated with the presence of Microcystis spp., particularly Microcystis aeruginosa, a highly toxic cyanobacterium that commonly forms blooms in lakes and reservoirs throughout the world (Gkelis and Zautsos, 2014; Mowe et al., 2015; Hayes and Vanni, 2018). However,
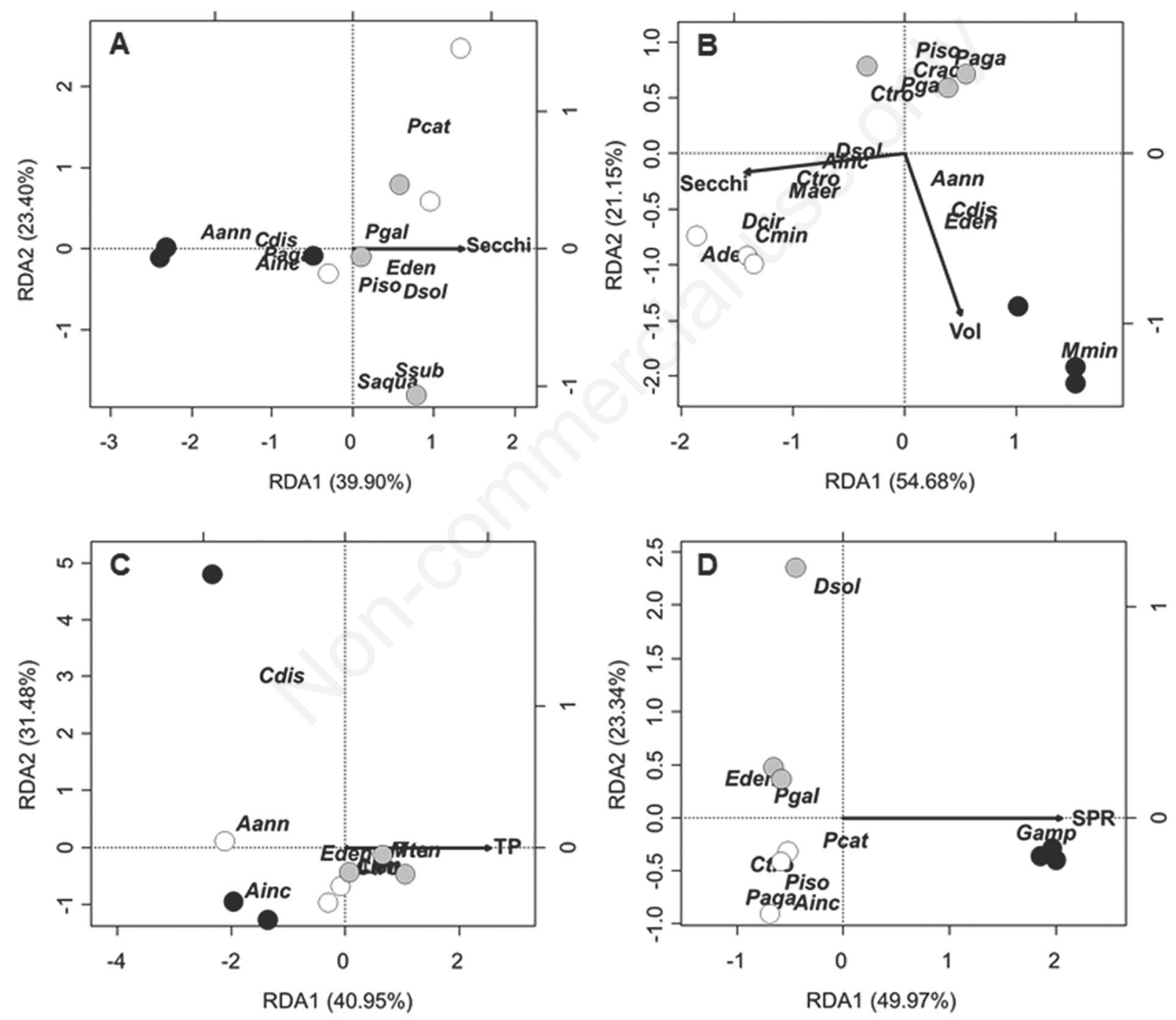

Fig. 4. RDA biplot showing the relationship between abiotic variables and Cyanobacteria in Boqueirão (A), Camalaú (B), Mucutú (C) and Poções (D) reservoirs. ○, October 2016; •, February 2017; •, June 2017; Aann, Aphanocaspa annulata; Adel, Aphanocaspa delicatissima; Ainc, Aphanocaspa incerta; Cdis, Chroococcus dispersus; Crac, Cylindrospermopsis raciborskii; Ctro, Cuspidothrix tropicalis; Dcir, Dolichospermum circinale; Dsol, Dolichospermum solitarium; Eden, Eucapis densa; Gamp, Geitlerinema amphibium; Llim, Limnococcus limneticus; Maer, Microcystis aeruginosa; Mmin, Merismopedia minima; Mten, Merismopedia tenuissima; Paga, Plankthotrix agardhii; Pcat, Pseudonabaena catenata; Pgal, Pseudanabaena galeata; Piso, Plankthotrix isothrix; Saqua, Synechocystis aquatilis; Ssub, Spirulina subsalsa; Secchi, water transparency; Vol, water volume; SRP, soluble reactive phosphorus; TP, total phosphorus. 
microcystins are produced by other cyanobacterial species of genera such as Oscillatoria, Aphanizomenon, Merismopedia, Nostoc, Anabaena, Phormidium, Planktothrix, and Anabaenopsis (Bernard et al., 2016).

In this study, a linear correlation between microcystin and potential producing species such as $P$. agardhii, $P$. isothrix, and $P$. galeata was found in Boqueirão, Camalaú and Mucutú reservoirs. Microcystis aeruginosa was identified in the Camalaú Reservoir, but had a negative relationship with microcystin content. Planktothrix species are known to form intense blooms in semi-arid reservoirs, and the detection of microcystin has been mainly associated with the presence of $P$. agardhii (Bittencourt-Oliveira et al., 2014; Fonseca et al., 2015; Lorenzi et al., 2018).

The positive relationship between $C$. raciborskii and microcystin in the Camalaú reservoir was unexpected, since to date there is no record of strains of this species producing this cyanotoxin. Recently, Panou et al. (2018) detected fragments of the microcystin synthetase gene in C. raciborskii strains isolated from Greece, suggesting a need for further studies on the metabolic diversity of this cyanobacterium.A survey of the tropical zone of America showed that about $47 \%$ of cyanoHABS (cyanobacterial harmful algal blooms) are formed by members of the genus Cylindrospermopsis, especially $C$. raciborskii (Mowe et al., 2015). Phytogeographic studies have demonstrated the tropical origin of this cyanobacterium and emphasized its expansion in the last decades to temperate regions, as an invasive species that form dense blooms (Antunes et al., 2015).

Cylindrospermopsin is a key secondary metabolite produced by $C$. raciborskii (Ohtani et al., 1992), which explains the significant positive relationship between them in the Camalaú reservoir. This cyanotoxin is produced by other filamentous cyanobacteria such as Anabaena bergii, Aphanizomenon ovalisporum, A. flosaquae, Oscillatoria sp. PCC6506, Sphaerospermopsis aphanizomenoides, and Umezakia natans (Armah et al., 2013; Rzymski and Poniedziałek, 2014). The low frequency of cylindrospermopsin detection in the reservoirs we investigated agrees with the findings of studies on reservoirs in the semi-arid region of the Northeast of Brazil (Costa et al., 2006; BittencourtOliveira et al., 2014).

In the present study, saxitoxin was the second most frequent cyanotoxin and the second cyanotoxin with the highest number of potential producers. The presence of the toxin was significantly correlated with the filamentous cyanobacterium G. amphibium in Mucutú Reservoir. Saxitoxins are the most potent natural toxins known with a lethal dose $50\left(\mathrm{LD}_{50}\right)$ (i.e. the dose that causes the death of $50 \%$ exposed individuals) of $10 \mu \mathrm{g} \mathrm{Kg}^{-1}$. There are 57 identified analogues of saxitoxins (Wiese et al., 2010)
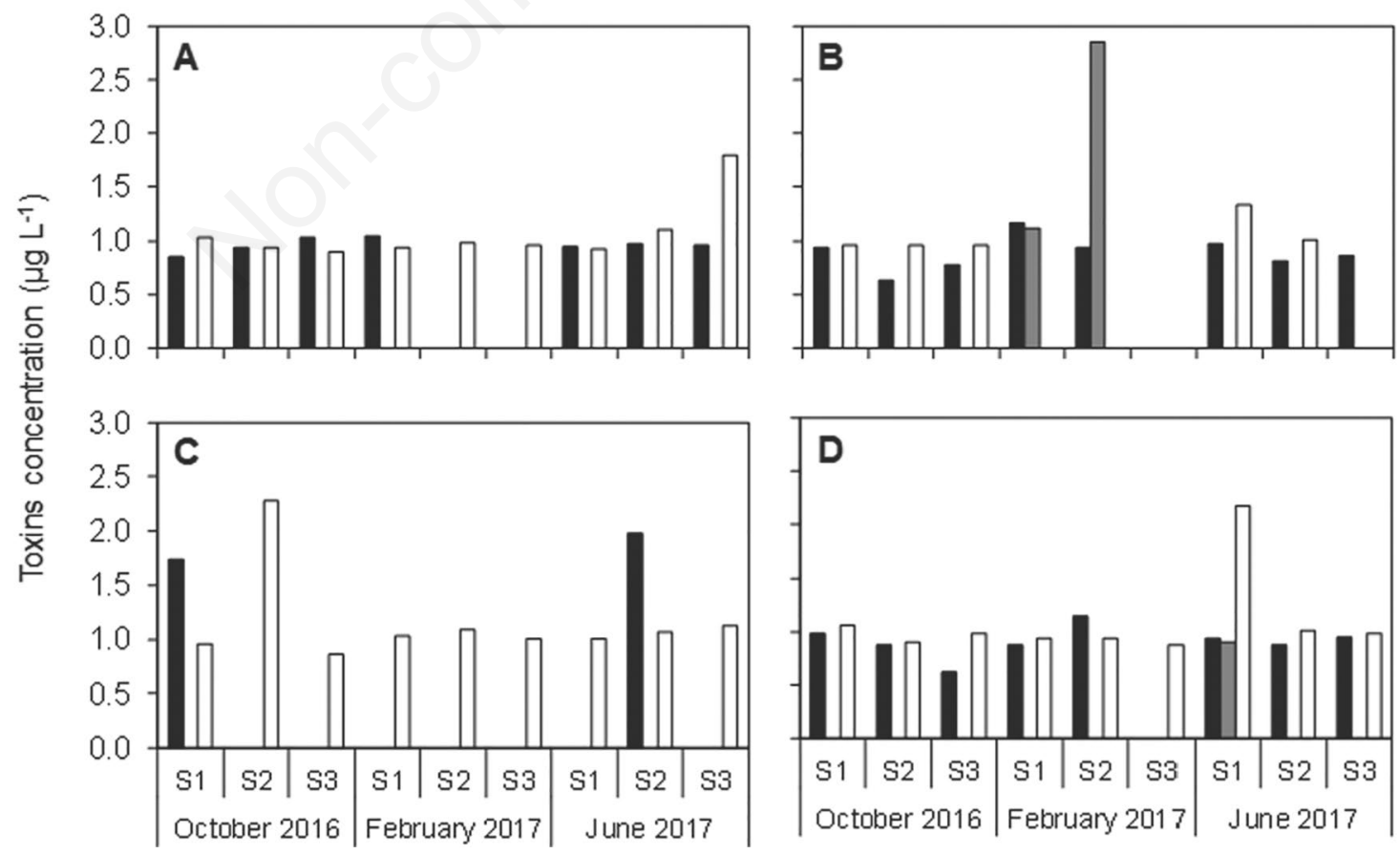

Fig. 5. Cyanotoxin concentrations in Boqueirão (A), Camalaú (B), Mucutú (C) and Poções (D) reservoirs in October 2016 and February

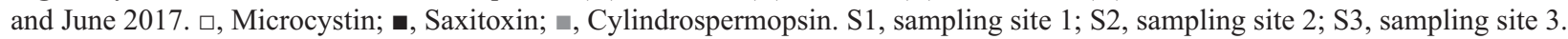


produced by freshwater cyanobacteria (Anabaena, Aphanizomenon, Cylindrospermopsis, Lyngbya, Planktothrix, Raphidiopsis, and Scytonema) and marine dinoflagellates (Hackett et al., 2012; Boopathi and Ki, 2014). Although it does not form blooms, the saxitoxins producer Geitlerinema is one of the most commonly occurring genera in semi-arid reservoirs (Aragão-Tavares et al., 2013). In Ingazeira, Geitlerinema amphibium was found in $100 \%$ of the samples obtained from a monthly survey conducted between 2012 and 2013 in Ipojuca and Pedra reservoirs, State of Pernambuco-Brasil (AragãoTavares et al., 2017).

The abiotic variables that explained the variations in the biomass of cyanobacteria and the concentration of cyanotoxins in our study were nutrients (total and dissolved forms of phosphorus), the water volume of the reservoirs, and the availability of light in the water column (transparency and turbidity). These results corroborate the
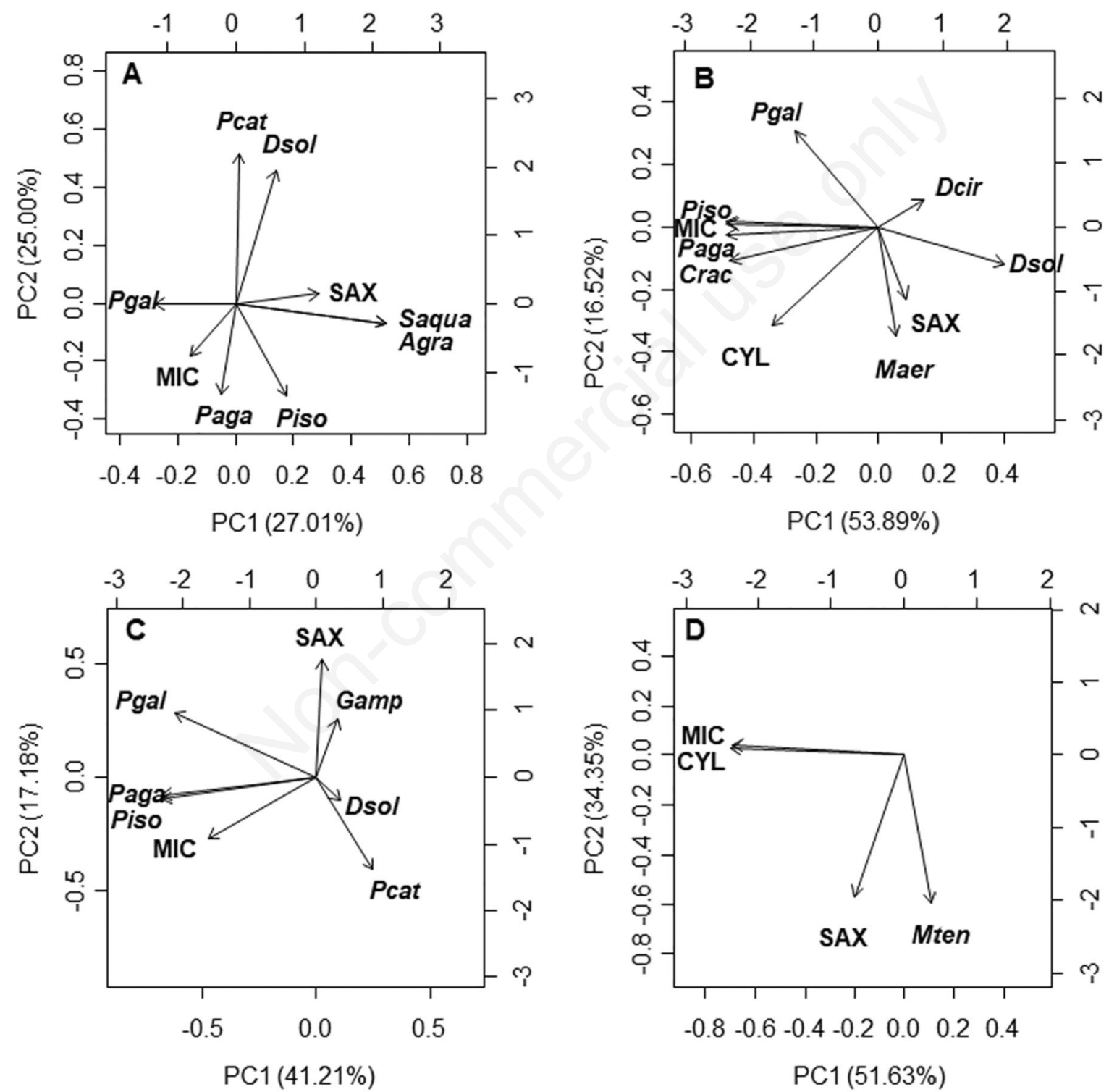

Fig. 6. PCA biplot with the Cyanobacteria species and cyanotoxins of the Boqueirão (A), Camalaú (B), Mucutú (C) and Poções (D) reservoirs. Species with biovolume equal to or less than $1 \%$ of the total biovolume of cyanobacteria were not included in the analysis. Aann, Aphanocaspa annulata; Ainc, Aphanocaspa incerta; Cdis, Chroococcus dispersus; Dcir, Dolichospermum circinale; Dsol, Dolichospermum solitarium; Eden, Eucapis densa; Gamp, Geitlerinema amphibium; Maer, Microcystis aeruginosa; Mmin, Merismopedia minima; Paga, Plankthotrix agardhii; Piso, Plankthotrix isothrix; Pcat, Pseudonabaena catenata; Pgal, Pseudanabaena galeata; MIC, total microcystins; SAX, total saxitoxins; CYL, total cylindrospermopsins. 
hypothesis that similar physicochemical conditions influence the abundance and diversity of cyanobacteria and cyanotoxins. These results are in agreement with those observed in lakes that have a strong relationship between cyanotoxins and cyanobacteria biovolume/biomass (Graham et al., 2004; Wang Q. et al., 2010).

In this study, the variables described as predictors of cyanobacteria and cyanotoxins have been implicated in facilitating the formation of cyanoHABs in semi-arid reservoirs in Brazil (Dantas et al., 2011; Rocha et al., 2018). Nutrients are important triggers for the development of cyanobacterial blooms (Merel et al., 2013), since excessive nutrient loads cause alterations in the trophic state and, consequently, increase in algal biomass (Cao et al., 2016). Phosphorus is a major limiting nutrient of cyanobacteria, particularly the dissolved form (Kotak et al., 2000; Brasil et al., 2016; Descy et al., 2016) that is directly assimilated by primary producers. This explains the significant positive correlation found
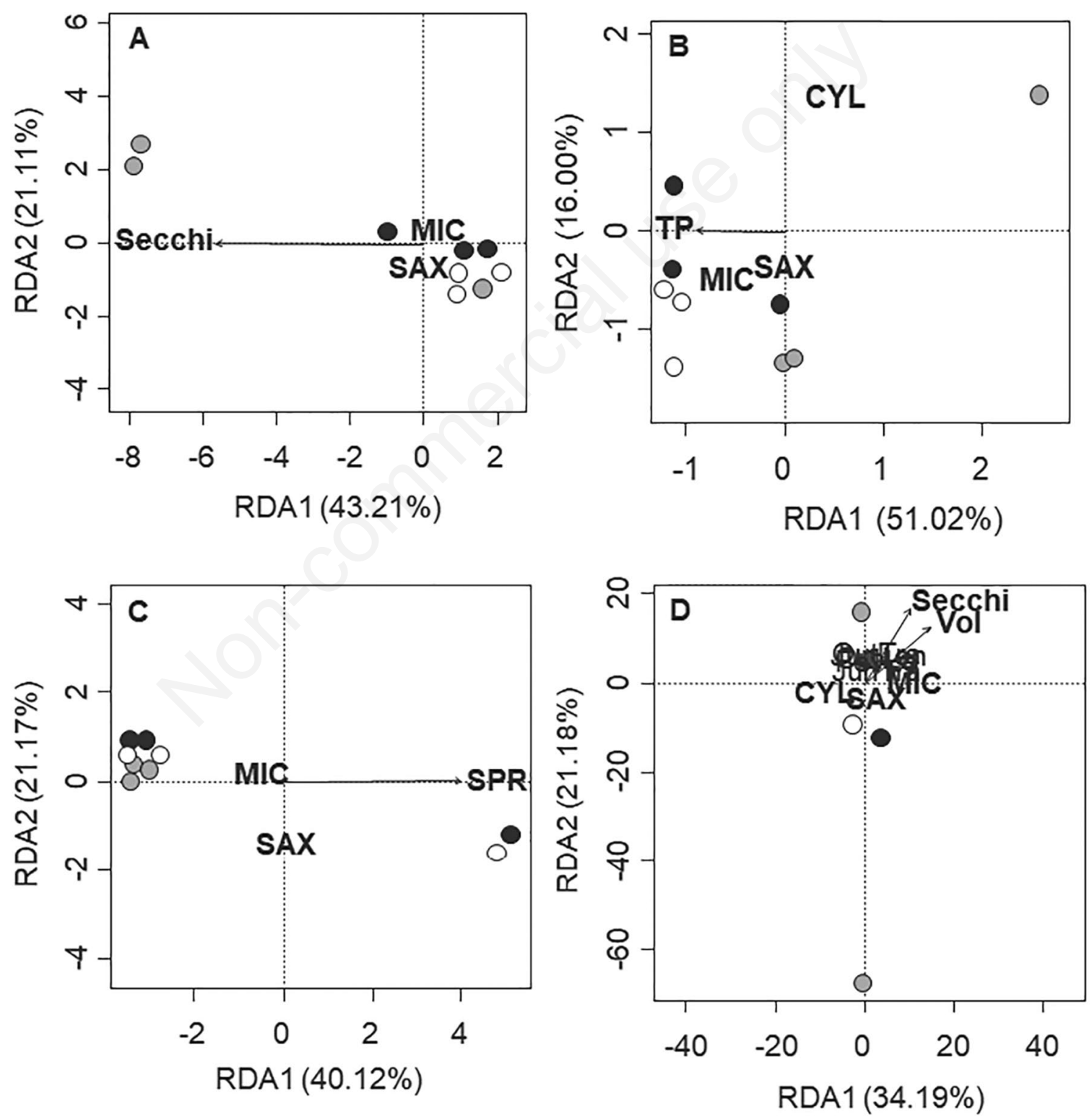

Fig. 7. RDA biplot with abiotic variables and cyanotoxins of the Boqueirão (A), Camalaú (B), Mucutú (C) and Poções (D) reservoirs. ○, October 2016; •, February 2017; •, June 2017; Mic, total microcystins; Sax, total saxitoxins; Cyl, total cylinderspermopsins; Secchi, water transparency; Vol, water volume; SRP, soluble reactive phosphorus; TP, total phosphorus. 
between this nutrient and several potential toxin producing species of cyanobacteria (G. amphibium and M. tenuissima) in our study.

In addition to nutrients, studies have also highlighted the importance of temperature as a trigger for increased cyanobacterial abundance and cyanotoxin concentration (Rigosi et al., 2015; Cunha et al., 2018). In our study, the effect of temperature on cyanobacterial biomass and cyanotoxins content was not significant, and this is due to the fact that the investigated reservoirs have high temperatures $\left(>25^{\circ} \mathrm{C}\right)$ throughout the year, a situation that is characteristic of semi-arid aquatic ecosystems. This condition favors the development of cyanobacteria and formation of perennial blooms (Bouvy et al., 1999; Moura et al., 2011; Moura et al., 2018; Portella et al., 2018).

The association between cyanobacteria and light availability (water transparency and turbidity) is common in eutrophic reservoirs with high suspended organic matter in the form of cyanobacteria cells (Graham et al., 2004; Dalu and Wasserman, 2018). Thus, cyanobacterial blooms cause an increase in the concentration of suspended particles in the water column and, consequently, reduction of transparency, increase in turbidity, and reduction in the quality and quantity of light available for competiting species. While the reduction in light availability is detrimental to the growth of most phytoplankton species, bloom-forming cyanobacteria have ecophysiological strategies that allow them to remain suspended in the region of the water column with the most photon irradiation using gas vesicles to increase their buoyancy, and are well adapted to changing light conditions (Reynolds et al., 1987).

The influence of the water volume on the cyanobacteria diversity and abundance observed in our study is in agreement with findings from other semi-arid reservoirs. The reduction of water volume intensifies the formation of cyanoHABs (Brasil et al., 2016; Rocha Junior et al., 2018), but the effects on cyanotoxins are still poorly understood. Thus, further investigations are needed on the effects of water volume on cyanotoxins production, as semi-arid reservoirs in Brazil are often exposed to prolonged droughts (Rocha Junior et al., 2018), which may increase the risks of human exposure to these bioactive metabolites.

\section{CONCLUSIONS}

There was a significant correlation between cyanotoxins and the biomass of potential producing species, but there were situations where cyanotoxins were detected without the presence of potential producers. These results demonstrate the need for reassessment of potential toxin producing species of cyanobacteria in semi-arid reservoirs. This may lead to the identification and characterization of novel producers of these bioactive secondary metabolites.

Also, total and dissolved phosphorus, the water volume of the reservoirs, and availability of light (water transparency and turbidity) in the water column significantly influence the community structure and dynamics of cyanobacteria and their toxins in the investigated aquatic ecosystems.

\section{REFERENCES}

Alvares CA, Stape JL, Sentelhas PC, de Moraes G, Leonardo J, Sparovek G, 2013. Köppen's climate classification map for Brazil. Meteorol. Z. 22:711-728.

Antunes JT, Leão PN, Vasconcelos VM, 2015. Cylindrospermopsis raciborskii: review of the distribution, phylogeography, and ecophysiology of a global invasive species. Front. Microbiol. 6: 473.

Aragão-Tavares NKC, Moura AN, Bittencourt-Oliveira MC, 2013. Planktonic Cyanobacteria forming blooms in reservoirs of northeastern Brazil. Rev. Bras. Cienc. Agrar. 8:662-668.

Aragão-Tavares NKC, Moura AN, Dantas ÊW, 2017. Persistence and stability of phytoplankton communities in eutrophic reservoirs of northeastern Brazil. Braz J Bot. 40:749-759.

Araújo LE, Neto JMM, Sousa FAS, 2009. Classification of annual rainfall and the rainy quarter of the year in the Paraíba river basin using Rain Anomaly Index (RAI). Rev. Ambient. Água. 4: 93-110.

Armah A, Hiskia A, Kaloudis T, Chernoff N, Hill D, Antoniou MG, He X, Loftin K, O’Shea K, Zhao C, Pelaez M, Han C, Lynch TJ, 2013. A review on cylindrospermopsin: the global occurrence, detection, toxicity and degradation of a potent cyanotoxin. Environ. Sci. Process Impacts 15:1979-2003.

APHA, 2012. Standard methods for the examination of water and wastewater. APHA, Wahsington DC.

Barbosa JEL, Medeiros ESFM, Brasil J, Cordeiro RS, Crispim MCB, Silva GHG, 2012. Aquatic systems in semi-arid Brazil: limnology and management. Acta Limnol Bras. 24:103-118.

Bernard C, Ballot A, Thomazeau S, Maloufi S, Furey A, Mankiewicz-Boczek J, Pawlik-Skowrońska B, Capelli C, Salmaso N, 2016. Appendix 2: Cyanobacteria associated with the production of cyanotoxins. In: J. Meriluoto, L. Spoof and G.A. Codd (eds.), Handbook of cyanobacterial monitoring and cyanotoxin analysis. J. Wiley \& Sons, Ltd, Chichester.

Bittencourt-Oliveira MC, Piccin-Santos V, Kujbida P, Moura $\mathrm{AN}, 2011$. Cylindrospermopsin in water supply reservoirs in Brazil determined by immunochemical and molecular methods. J. WaterResour. 3:349-355.

Bittencourt-Oliveira MC, Santos DMS, Moura NA, 2010. Toxic cyanobacteria in reservoirs in northeastern Brazil: detection using a molecular method. Braz. J. Biol. 70:1005-1010.

Bittencourt-Oliveira MCD, Piccin-Santos V, Moura AN, Aragão-Tavares NK, Cordeiro-Araújo MK, 2014. Cyanobacteria, microcystins and cylindrospermopsin in public drinking supply reservoirs of Brazil. Na. Acad. Bras. Cienc. 86:297-310. 
Boopathi T, Ki JS, 2014. Impact of environmental factors on the regulation of cyanotoxin production. Toxins 6:1951-1978.

Bouvy M, Molica M, Oliveira S, Marinho M, Beker B, 1999. Dynamics of a toxic cyanobacterial bloom (Cylindrospermopsis raciborskii) in a shallow reservoir in the semi-arid region of northeast Brazil. Aquat. Microb. Ecol. 20:285-297.

Brasil J, Attayde JL, Vasconcelos FR, Dantas DD, Huszar VL, 2016. Drought-induced water-level reduction favors cyanobacteria blooms in tropical shallow lakes. Hydrobiologia 770:145-164.

Buratti FM, Manganelli M, Vichi S, Stefanelli M, Scardala S, Testai E, Funari E, 2017. Cyanotoxins: Producing organisms, occurrence, toxicity, mechanism of action and evaluation toxicological risk to human health. Arch. Toxicol. 91:10491130.

Cao X, Wang J, Liao J, Sun J, Huamg Y, 2016. The threshold response of phytoplankton community to nutriente gardient in a shallow eutrophic Chinese lake. Ecol. Indic. 61:258-267.

Carlson RE, 1977. Atrophic state index for lakes. Limnol. Oceanogr. 22:361-369.

Carmichael WW, 1992. Cyanobacteria secondary metabolites the cyanotoxins. J. Appl. Bacteriol. 72:445-459.

Chia MA, Cordeiro-Araújo MK, Lorenzi AS, BittencourtOliveira MCD, 2017. Cylindrospermopsin induced changes in growth, toxin production and antioxidant response of Acutodesmus acuminatus and Microcystis aeruginosa under differing light and nitrogen conditions. Ecotox. Environ. Safe. 142:189-199.

Chia MA, Jankowiak JG, Kramer BJ, Goleski JA, Huang IS, Zimba PV, Bittencourt-Oliveira MC, Gobler CJ, 2018. Succession and toxicity of Microcystis and Anabaena (Dolichospermum) blooms are controlled by nutrientdependent allelopathic interactions. Harmful Algae 74:67-77.

Chorus I, Bartram J, 1999. Toxic cyanobacteria in water: a guide to the public health consequences, monitoring and management. Spon Press, London: 440 pp.

Costa IAS, Azevedo SMF, Senna PAC, Bernardo RR, Costa SM, Chellappa NT, 2006. Occurrence of toxin-producing cyanobacteria blooms in a Brazilian semiarid reservoir. Braz. J. Biol. 66:211-219.

Cunha DGF, Dodds WK, Loiselle SA, 2018. Factors related to water quality and thresholds for microcystin concentrations in subtropical Brazilian reservoirs. Inland Waters 8:368-380.

Dalu T, Wasserman RJ, 2018. Cyanobacteria dynamics in a small tropical reservoir: Understanding spatio-temporal variability and influence of environmental variables. Sci. Total Environ. 643:835-841.

Dantas EW, Moura AN, Bittencourt-Oliveira MDC, 2011. Cyanobacterial blooms in stratified and destratified eutrophic reservoirs in semi-arid region of Brazil. Ann. Acad. Bras. Cienc. 83:1327-1338.

Descy JP, Leprieur F, Pirlot S, Leporcq B, Van Wichelen J, Peretyatkp A, Teissier S, Codd GA, Triest L, Vyverman W, Wilmotte A, 2016. Identifying the factors diterming blooms of cyanobacteria in a set of shallow lakes. Ecol. Inform. 34:129-138.

Dolman AM, Rücker J, Pick FR, Fastner J, Rohrlack T, Mishke U, Wiedner C, 2012. Cyanobacteria and Cyanotoxins: The influence of nitrogen versus phosphorus. PloS One 7:e38757.

Downing TG, Phelan RR, Downing S, 2015. A potential physiological role for cyanotoxins in cyanobacteria of arid environments. J. Arid. Environ. 112:147-151.

Figueredo C, Pinto-Coelho RM, Lopes AMMB, Lima PHO, Gücker B, Giani A, 2016. From intermittent flowering to persistent cyanobacteria: identifying the main vectors in an urban tropical reservoir. J. Limnol. 75:445-454. doi: 10.4081/jlimnol.2016.1330.

Fortin N, Aranda-Rodriguez R, Jing H, Pick F, Bird D, Greer $\mathrm{CW}$, 2010. Detection of microcystin - producing cyanobacteria in Missiquoi Bay, Quebec, Canada, using quantitative PCR. Appl. Environ. Microb. 76:5105-5112.

Freitas EC, Pinheiro C, Rocha C, Loureiro S, 2014. Can mixtures of cyanotoxins represent a risk to the zooplankton? The case study of Daphnia magna Straus exposed to hepatotoxic and neurotoxic cyanobacterial extracts. Harmful Algae 31:143-152.

Fonseca JR, Vieira PCS, Kujbida P, Costa IAS, 2015. Cyanobacterial occurrence and detection of microcystins and saxitoxins in reservoirs of the Brazilian semi-arid. Acta Limnol. Bras. 27: 8-92.

Funari E, Testai E, 2008. Human health risk assessment related to cyanotoxins exposure. Crit. Rev. Toxicol. 38:97-125.

Gao Y, Cornwell JC, Stoecker DKE, Owens MS, 2012. Effects of $\mathrm{pH}$ increase by cyanobacteria on sediment nutrient fluxes and nitrification-denitrification coupled in a shallow freshwater estuary. Biogeosciences 9:2697-2710.

Ger KA, Hansson LA, Lürling M, 2014. Understanding cyanobacteria $\square$ zooplankton interactions in a more eutrophic world. Freshwater Biol. 59:1783-1798.

Gkelis S, Zaoutsos N, 2014. Cyanotoxin occurrence and potentially toxin producing cyanobacteria in freshwaters of Greece: A multi-disciplinary approach. Toxicon 78:1-9.

Graham JL, Jones JR, Jones SB, Downing JA, Clevenger TE, 2004. Environmental factors influencing microcystin distribution and concentration in the Midwestern United States. Water Res. 38:4395-4404.

Hackett JD, Wisecaver JH, Brosnahan ML, Kulis DM, Anderson DM, Bhattacharya D, Erdner DL, 2012. Evolution of saxitoxin synthesis in cyanobacteria and dinoflagellates. Mol Biol Evol. 30:70-78.

Hayes NM, Vanni MJ, 2018. Microcystin concentrations can be predicted with phytoplankton biomass and watershed morphology. Inland Waters 8:273-283.

Hillebrand H, Dŭrselen C, Kírsctel D, Polligher U, Zohary T, 1999. Biovolume calculation for pelagic and benthic microalgae. J. Phycol. 35:403-424.

Huang J, Ji M, Xie Y, Wang S, He Y, Ran J, 2016. Global semiarid climate change over last 60 years. Clim. Dynam. 46:1131-1150.

Jespersen AM, Christoffersen K, 1987. Measurements of chlorophyll-a from phytoplankton usig etanol as extraction solvente. Arch. Hydrobiol. 109 445-454.

Jones GJ, Orr PT, 1994. Release and degradation of microcystin following algicide treatment of a Microeystis aeruginosa bloom in a recreational lake, as determined by HPLC and protein phosphatase inhibition assay. Water Res. 28: 871-876.

Jovem-Azevêdo D, Bezerra-Neto JF, Azevêdo EL, Gomes WIA, 
Molozzi J, Feio MJ, 2019. Dipteran assemblages as functional indicators of extreme droughts. J. Arid Environ. 164:12-22.

Kaebernick M, Neilan BA, 2001. Ecological and molecular investigations of cyanotoxin production. Microb. Ecol. 35:1-9.

Komárek J, 2013. Süßwasserflora von Mitteleuropa, Bd. 19/3: Cyanoprokaryota. rd part: Heterocytous Genera. Springer Spektrum: $1130 \mathrm{pp}$.

Komárek J, Anagostidis K, 1989. Modern approach to the classification system of cyanophytes 4- Nostocales. Arch. Hydrobiol. 56:247-345.

Komárek J, Anagnostidis K, 1999. Cyanoprokaryota. 1. Teil: Chroococcales. In: H. Ettl, G. Gärtner, H. Heynig, D. Mollenhauer (eds). Süsswasserflora von Mitteleuropa. 19/1. Springer Spektrum: 548 pp.

Komárek J, Anagostidis K, 2005. Cyanoprokaryota. 2. Teil: Oscillatoriales. In: B. Bündel, L. Krienitz, G. Gätner and M. Schagerl (eds.), Süsswasserflora von Mitteleuropa. Springer Spektrum: 759 pp.

Komárek J, Komárková-Lec-Nerová J, Sant'anna CL, Azevedo MTP, Senna PAC, 2002. Two common Mycrocystis species (Chroococcaales, Cyanobacteria) from tropical America, including M. panniformis sp. Algologie 23:159-177.

Kotak BG, Lam AK, Prepas EE, Hrudey SE, 2000. Role of chemical and physical variables in regulating microcystinLR concentration in phytoplankton of eutrophic lakes. Can. J. Fish. Aquat. Sci. 57:1584-1593.

Krol MS, Bronstert A, 2007. Regional integrated modelling of climate change impacts on natural resources and resource usage in semi-arid Northeast Brazil. Environ. Modell. Softw. 22:259-268.

Lahti K, 1997. Persistence of cyanobacterial hepatotoxin, microcystin-LR in particulate material and dissolved in lake water. Water Res. 31:1005-1012.

Lorenzen CJ, 1967. Determination of chlorophyll and pheopigments: Spectrofotometric equations. Limnol. Oceanogr.12: 343.

Lorenzi AS, Cordeiro-Araújo MK, Chia MA, BittencourtOliveira MC, 2018. Cyanotoxin contamination of semiarid drinking water supply reservoirs. Environ. Earth Sci. 77:595.

Lorenzi AS, Chia MA, Piccin-Santos V, Bittencourt-Oliveira MDC, 2015. Microcystins and cylindrospermopsins molecular markers for the detection of toxic cyanobacteria: a case study of northeastern Brazilian reservoirs. Limnetica. 34:269-282.

Mantzouki E, Lürling M, Fastner J, De Senerpont Domis L, WilkWoźniak E, Koreivienė J, Seelen L, Teurlincx S, Verstijnen Y, Krztoń W, Walusiak E, Karosienė J, Kasperovičienė J, Savadova K, Vitonytė I, Cillero-Castro C, Budzyńska A, Goldyn R, Kozak A, Rosińska J, Szeląg-Wasielewska E, Domek P, Jakubowska-Krepska N, Kwasizur K, Messyasz B, Pełechata A, Pełechaty M, Kokocinski M, García-Murcia A, Real M, Romans E, Noguero-Ribes J, Duque DP, FernándezMorán E, Karakaya N, Häggqvist K, Demir N, Beklioğlu M, Filiz N, Levi EE, Iskin U, Bezirci G, Tavşanoğlu ÜN, Özhan K, Gkelis S, Panou M, Fakioglu Ö, Avagianos C, Kaloudis T, Çelik K, Yilmaz M, Marcé R, Catalán N, Bravo AG, Buck M, Colom-Montero W, Mustonen K, Pierson D, Yang Y, Raposeiro PM, Gonçalves V, Antoniou MG, Tsiarta N, McCarthy V, Perello VC, Feldmann T, Laas A, Panksep K,
Tuvikene L, Gagala I, Mankiewicz-Boczek J, Yağcı MA, Çınar Ş, Çapkın K, Yağcı A, Cesur M, Bilgin F, Bulut C, Uysal R, Obertegger U, Boscaini A, Flaim G, Salmaso N, Cerasino L, Richardson J, Visser PM, Verspagen JMH, Karan T, Soylu EN, Maraşlığlu F, Napiórkowska-Krzebietke A, Ochocka A, Pasztaleniec A, Antão-Geraldes AM, Vasconcelos V, Morais J, Vale M, Köker L, Akçaalan R, Albay M, Špoljarić Maronić D, Stević F, Žuna Pfeiffer T, Fonvielle J, Straile D, Rothhaupt K-O, Hansson L-A, Urrutia-Cordero P, Bláha L, Geriš R, Fránková M, Koçer MAT, Alp MT, Remec-Rekar S, Elersek T, Triantis T, Zervou S-K, Hiskia A, Haande S, Skjelbred B, Madrecka B, Nemova H, Drastichova I, Chomova L, Edwards C, Sevindik TO, Tunca H, Önem B, Aleksovski B, Krstić S, Vucelić IB, Nawrocka L, Salmi P, Machado-Vieira D, De Oliveira AG, Delgado-Martín J, García D, Cereijo JL, Gomà J, Trapote MC, Vegas-Vilarrúbia T, Obrador B, Grabowska M, Karpowicz M, Chmura D, Úbeda B, Gálvez JÁ, Özen A, Christoffersen KS, Warming TP, Kobos J, Mazur-Marzec H, Pérez-Martínez C, RamosRodríguez E, Arvola L, Alcaraz-Párraga P, Toporowska M, Pawlik-Skowronska B, Niedźwiecki M, Pęczuła W, Leira M, Hernández A, Moreno-Ostos E, Blanco JM, Rodríguez V, Montes-Pérez JJ, Palomino RL, Rodríguez-Pérez E, Carballeira R, Camacho A, Picazo A, Rochera C, Santamans AC, Ferriol C, Romo S, Soria JM, Dunalska J, Sieńska J, Szymański D, Kruk M, Kostrzewska-Szlakowska I, Jasser I, Žutinić P, Gligora Udovič M, Plenković-Moraj A, Frąk M, Bańkowska-Sobczak A, Wasilewicz M, Özkan K, Maliaka V, Kangro K, Grossart H-P, Paerl HW, Carey CC, Ibelings BW, 2018. Temperature effects explain continental scale distribution of cyanobacterial toxins. Toxins 10: pii: E156. doi: $10.3390 /$ toxins 10040156 .

Martins ESPR, De Nys E, Molejón C, Biazeto B, Silva RFV, Engle N, 2015. [Monitor de secas do nordeste, em busca de um novo paradigma para a gestão de secas].[Report in Portuguese]. Água Brasil Séries, no. 10. World Bank Group, Washington, D.C.

Merel S, Villarín MC, Chung K, Snyder S, 2013. Spatial and thematic distribution of research on cyanotoxins. Toxicon 76:118-131.

Mohamed ZA, 2017. Macrophytes - cyanobacteria allelopathic interactions and their implications for water resources management - A review. Limnologica 63:122-132.

Monchamp ME, Pick FR, Beisner BE, Maranger R, 2014. Nitrogen forms influence microcystin concentration and composition via changes in cyanobacterial community structure. PloS One 9:e85573.

Moura AN, Aragão-Tavares NKC, Amorim CA, 2018. Cyanobacterial blooms in freshwaters bodies in a semiarid region, northeastern Brazil. J. Limnol. 77:179-188. doi: 10.4081/jlimnol.2017.1646.

Moura AN, Dantas EW, Oliveira HSB, Bittencourt-Oliveira, MC, 2011. Vertical and temporal dynamics of cyanobacteria in the Carpina potable water reservoir in northeastern Brazil. Braz J Biol. 71: 451-459.

Mowe MA, Mitrovic SM, Lim RP, Furey A, Yeo DC, 2015. Tropical cyanobacterial blooms: a review of prevalence, problem taxa, toxins and influencing environmental factors. J Limnol. 74:205-224. doi: 10.4081/jlimnol.2014.1005.

Naselli-Flores L, Barone R, Chorus I, Kurmayer R, 2007. Toxic 
cyanobacterial blooms in reservoirs under a semiarid Mediterranean climate: the magnification of a problem. Environ. Toxicol. 22: 399-404.

O'Neil JM, Davis TW, Burford MA, Glober CJ, 2012. The rise of harmul cyanobacteria blooms: The potential roles of eutrophication and climate change. Harmful Algae 14:313334.

Ohtani I, Moore RE, Runnegar MT, 1992. Cylindrospermopsin: a potent hepatotoxin from the bluegreen alga Cylindrospermopsis raciborskii. J. Am. Chem. Soc. 114:7941-7942.

Omidi A, Esterhuizen-Londt M, Pflugmacher S, 2018. Still challenging: the ecological function of the cyanobacterial toxin microcystin-What we know so far. Toxin Rev. 37:87-105.

Paerl H, Otten TG, 2013. Flora of harmful cyanobacteria: causes, consequences and controls. Microb. Ecol. 65:9951010.

Paerl HW, Hall NS, Calandrino ES, 2011. Controlling harmful cyanobacterial blooms in a world experiencing anthropogenic and climatic- induced change. Sci. Total Environ. 409:1739-1745.

Paerl HW, Huisman J, 2009. Climate change: a catalyst for global expansion of harmful cyanobacterial blooms. Environ. Microbiol. Rep. 1:27-37.

Paerl HW, Otten TG, Joyner AR, 2016. Moving towards adaptive management of cyanotoxin-impaired water bodies. Microbiol. Biotechnol. 9:641-651.

Paerl HW, Paul VJ, 2012. Climate change: Links to global expansion of harmful cyanobacteria. Water Res. 46:13491363.

Panou M, Zervou SK, Kaloudis T, Hiskia A, Gkelis S, 2018. A Greek Cylindrospermopsis raciborskii strain: Missing link in tropic invader's phylogeography tale. Harmful Algae 80:96-106.

Pawlik-Skowronska B, Toporowska M, 2016. How to mitigate cyanobacterial blooms and cyanotoxin production in eutrophic water reservoirs? Hydrobiologia 778:45-59.

Piccin-Santos V, Bittencourt-Oliveira MC, 2012. toxic cyanobacteria in four brazilian water supply reservoirs. J. Environ. Prot. 3:68-73.

Portella FHCO, Moura AN, Dantas EW, 2018. Variation in climate determines differences in the effects of abiotic variables on the phytoplankton community in tropical ecosystems. Mar. Freshwater Res. 69: 357.

Ragab R, Prudhomme C, 2002. SW-Soil and Water: Climate change and water resources management in arid and semiarid regions: prospective and challenges for the $21 \mathrm{st}$ Century. Biosyst. Eng. 81: 3-34.

Reynolds CS, Oliver R L, Walsby AE, 1987. Cyanobacterial dominance: The role of buoyancy regulation in dynamic lake environments. N. Zeal. J. Mar. Fresh. 21:379-390.

Rigosi A, Hanson P, Hamilton DP, Hipsey M, Rusak JA, Bois J, Kim B, 2015. Determining the probability of cyanobacterial blooms: the application of Bayesian networks in multiple lake systems. Ecol. Appl. 25:186-199.

Rocha Junior CAN, Costa MRA, Menezes RF, Attayde JL, Becker V, 2018. Water volume reduction increases eutrophication risk in tropical semi-arid reservoirs. Acta Limnol. Bras. 30:e106.

Rojo C, Segura M, Cortés F, Rodrigo MA, 2013. Alelopathic effects of microcystin-LR on the germination, growth and metabolismo of five charophyte species and a submerged angiosperm. Aquat. Toxicol. 144-145:1-10.

Ross J, 1979. [Práticas de ecologia].[Book in Spanish]. Omega, Barcelona: $181 \mathrm{pp}$.

Rzymski P, Poniedziałek B, 2014. In search of environmental role of cylindrospermopsin: a review on global distribution and ecology of its producers. Water Res. 66:320-337.

Sierosławska A, Rymuszka A, Kalinowska R, Skowroński T, Bownik A, Pawlik-Skowrońska B, 2010. Toxicity of cyanobacterial bloom in the eutrophic dam reservoir (Southeast Poland). Environ. Toxicol. Chem. 29:556-560.

Sinang SC, Poh KB, Shamsudin S, Sinden A, 2015. Preliminary assessment of cyanobacteria diversity and toxic potential in ten freshwater lakes in Selangor, Malaysia. Bull. Environ. Contam. Toxicol. 95:542-547.

Stocker TF, Qin D, Plattner GK, Tignor M, Allen SK, Boschung J, Midgley PM, 2013. Climate change 2013: The physical science basis. Intergovernmental Panel on Climate Change, Working Group I Contribution to the IPCC Fifth Assessment Report (AR5) (Cambridge Univ Press, New York). 25:1535.

Te SH, Gin KYH, 2011. The dynamics of cyanobacteria and microcystin production in a tropical reservoir by inferetial modelling. Harmful Algae. 10:319-329.

Ter Braak CJF, Prentice IC, 1988. The theory of gradient analysis. Adv. Ecol.Res. 18:271-317.

Toledo Jr AP, Talarico M, Chinez SJ, Agudo EG, 1983. [A aplicação de modelos simplificados para a avaliação de processo da eutrofização em lagos e reservatórios Tropicais], p. 1-34.[Article in Portuguese]. Proceedings of the 12th Congresso Brasileiro de Engenharia Sanitária, Rio de Janeiro, ABES.

Utermöhl H, 1958. [Zur Vervollkommnung der quantitative phytoplankton Methodik].[Article in German]. Mitt. Internat. Verein Limnol. 9:1-38.

Walls JT, Wyatt KH, Doll JC, Rubenstein EM, Rober AR, 2018. Hot and toxic: Temperature regulates microcystin release from cyanobacteria. Sci. Total Environ. 610-611:786-795.

Walter JM, Lopes FAC, Lopes-Ferreira M, Vidal LM, Leomil FM, Azevedo GS, Oliveira RMS, Medeiros AJ, Melo ASO, Rezende CED, Tanuri A, Thompson FL, 2018. Occurrence of harmful cyanobacteria in drinking water from a severely drought-impacted semi-arid region. Front. Microbiol. 9:176.

Wang X, Qin B, Gao G, Paerl HW, 2010. Nutrient enrichment and selective predation by zooplankton promote Microcystis (Cyanobacteria) bloom formation. J. Plankton Res. 32:457-470.

Wang Q, Niu Y, Xie P, Chen J, Ma Z, Tao, M, Guo L, 2010. Factors affecting temporal and spatial variations of microcystins in Gonghu Bay of Lake Taihu, with potential risk of microcystin contamination to human health. Sci. World J. 10:1795-1809.

Wiese M, D'agostino PM, Mihali TK, Moffitt MC, Neilan BA, 2010. Neurotoxic alkaloids: saxitoxin and its analogs. Mar. Drugs 8:2185-2211.

Yang H, Xie P, Xu J, Zheng L, Deng D, Zhou Q, Wu S, 2006. Seasonal variation of microcystin concentration in Lake Chaohu, a shallow subtropical lake in the People's Republic of China. Bull. Environ. Contam. Toxicol. 77:367-374. 